\title{
Essay
}

\section{BRICKS PLUS BYTES: HOW "CLICK-AND-BRICK" WILL DEFINE LEGAL EDUCATION SPACE}

\author{
Nicolas P. TERRY*
}

\section{INTRODUCTION}

$\mathrm{T}$ HE law school is the quintessential bricks-and-mortar institution. A university may share its identity with its sports teams or the town within which its gowns reside. In contrast, the law school always seems to be a place, dean candidates first ask about the building, accreditation teams check dimensions, and fundraising is often driven by building campaigns. The building is the key point of contact between faculty, students and alumni. Law school gatherings resonate with shared experiences of malfunctioning heating and air-conditioning systems, dubious acoustics and any number of infestations. Too often, it seems, we have focused on the place and less on the communities that function there. Only in the classroom do the bricks find any spiritual competition, and it is there that teachers have shown their greatest skepticism towards the bytes that serve as the metaphor for law school technology and, more specifically, for computer-mediated education.

After a faltering start, law schools (or, as frequently, their parent institutions) have dramatically increased their information technology ("IT") budgets and the professionalism of their IT staffs; law professors have stopped referring to their "studies" and discovered "home offices," and few students now attempt to navigate law school without a computer, word processor or Internet connectivity. Electronic research is now the preferred method, even though the same materials can usually be found between hard covers a few feet from the researcher's computer. Admissions departments have invested in a robust web presence, and law school development offices strive to build vital alumni extranets. Furthermore, ethernet cables snake through our walls and data projectors have sprouted

* Nicolas P. Terry, Professor of Law and Co-Director, Center for Health Law Studies, Saint Louis University School of Law (terry@slu.edu). I am indebted to many whose presentations I have attended and wisdom I have absorbed over the years on this subject, not least to Dean Henry Perritt of Chicago-Kent Law School and Professor Peter Martin of Cornell Law School. I also thank Steve Johnson for making available to me his thoughtful article, Stephen M. Johnson, www.lawschool.edu: Legal Education in the Digital Age, 2000 Wis. L. Rev. 85 (2000), available at http://merlin.law.mercer.edu/elaw/future.htm and the faculty of Villanova University School of Law where I workshopped this paper. John Mayer, Alan Weinberger, Ben Moulton, Michael Korybut, Bill Anderson, Jane Winn and Jeff Lewis were exceptionally generous with their time in commenting on earlier drafts of this article. The errors are mine alone. 
from our classroom ceilings, their monocular protrusions sadly looking for a professor, any professor to bring all those lumens to bare to better illuminate some students. ${ }^{1}$

While a few schools have the temerity to market themselves as technology leaders, most legal educators view bytes whizzing through our schools as necessary, but relatively unimportant, certainly less important than the bricks. Law school space, carefully defined and protected by those bricks, has seemed secure, its occupants and institutions relatively impervious to change. That comfort level is now under its most serious threat in generations, as law schools have begun to confront the issue of distance learning or distance education. ${ }^{2}$ Given a culture in which the label "major technology debate" heretofore has been applied to questions as weighty as whether WordPerfect and Word should both be supported, legal educators may find themselves ill-equipped to deal with even the basics of distance education ("DE") and related debates.

Herein, I present a number of technological, commercial and professional scenarios that cumulatively suggest that the law school of the near future must be re-engineered and become what is known in e-commerce as "click-and-brick" or "click-and-mortar." 3 In a click-and-brick law school, distributive learning techniques will fill much of the space, supplementing traditional class experiences and substituting for many others. But a true click-and-brick will also integrate distance learning methodologies, reaching out to remote students, enabling collaboration with off-campus faculty and consuming remote content. ${ }^{4}$ I draw this not entirely happy conclusion from analyzing the commercial and technological forces that are simultaneously energizing and threatening traditional legal education, and from my belief that, properly re-engineered, the traditional law schools can retain their relevance and continue in their role as the guardians of the intellect of the law.

In the sections that follow, I first address the qualitative and institutional arguments frequently raised against such non-traditional legal education (Part II). ${ }^{5}$ I then suggest that the law school of the future will be quite a different place from the one we are familiar with, both because of the implications of the new enabling technologies (Part III) and because law school space is no longer a self-contained, autonomous and insulated

1. See generally John Mayer, Alternate Futures: The Future of Legal Education, in The History of American Legal. Education: Commentary and Primary Sources (Steven Sheppard ed., 1999) (discussing alternate futures for legal education)

2. See, e.g., http://www.utexas.edu/cc/cit/de/deprimer (last modified Sept. 1998) (exemplifying University of Texas approach to distance education).

3. For a discussion of "click-and-brick," see infra note 40 .

4. See generally Mayer, supra note 1 (delineating four potential law school models that overlap with models discussed herein).

5. For a discussion of arguments against non-traditional legal education, see infra notes 9-47 and accompanying text. 
environment (Part IV). ${ }^{6}$ I argue that, before we can aspire to a sustainable click-and-brick model, we will be forced to make some significant changes to how we fill our virtual and physical law school space (Part V). ${ }^{7}$ Finally, I suggest that, in designing our click-and-brick model, we pay particular attention to the ways in which law practice is being reshaped, and suggest other areas where the law school curriculum will require major re-tooling to be relevant to the Information Age (Part VI) ${ }^{8}$

\section{Terminology, Quality AND InStitutional IMPEdiments}

The debate over DE frequently accompanies questions concerning the efficacy of computer-mediated legal education. ${ }^{9}$ More specifically, DE tends to be confused with distributive learning. As to this latter issue, I use "distributive learning" to refer to virtual space "wrappers" that supplement traditional pedagogy occurring in real space. Typically these are course pages, e-mail and web-based discussion forums ${ }^{10}$ or interactive lessons ${ }^{11}$ that extend (and hence "distribute") the traditional classroom experiences of bricks-and-mortar resident students. Current distributive learning techniques are most likely to be asynchronous ${ }^{12}$ (albeit modular rather than open-ended), although a few tools, such as (video) conferencing $^{13}$ or chat, are synchronous. Modern ${ }^{14} \mathrm{DE}$ incorporates these techniques, but then captures two additional concepts; first, the use of computer-mediation as the primary method of "classroom" teaching, faculty-student ("F2S") and student-student ("S2S") interaction; and, second, the almost correlate acknowledgment that students and faculty inter $s e$ are, by default, in geographically distinct places. Almost by definition, in a click-and-brick environment, distance and distributive models will

6. For a discussion of arguments concerning the law school as a non self-contained environment, see infra notes $67-93$ and accompanying text.

7. For a discussion of arguments concerning how to sustain a click-and-brick model, see infra notes 94-145 and accompanying text.

8. For a discussion of designing the click-and-brick model in the Information Age, see infra notes 146-234 and accompanying text.

9. See generally Howard Mintz, Law School Online (Nov. 14, 1999) (noting different viewpoints of legal scholars concerning distance education), at http:// www.mercurycenter.com/sutech/news/indepth/docs/law111599.htm.

10. See, e.g., http://webboard.oreilly.com (last visited Feb. 18, 2001) (providing web-based discussion and chat software that allows users to access web-based discussion forums).

11. See, e.g., http://lessons.cali.org/catalog.html (last visited Feb. 18, 2001) (providing interactive, computer-based lessons for various legal education subject areas).

12. In this context "asynchronous communication" refers to a communicative experience for which the parties do not have to be present at the same time. Thus, "e-mail" is asynchronous, although "chat" is synchronous.

13. See, e.g., http://www.microsoft.com/windows/netmeeting (last modified Feb. 1, 2001) (allowing users to download video conferencing software to assist in learning).

14. For a discussion of the contrasting, older, correspondence school model, see infra text accompanying note 25. 
start to coalesce, not only because of the common technologies employed, but also because schools will seek to expose their DE enrollees to "slices" of campus life. ${ }^{15}$

The issue of the effectiveness of computer-mediated learning obviously goes beyond terminology to the quality of the pedagogy and, ultimately, to the competence and professionalism of the "distance" law graduate. Computer-mediated instruction may be synchronous or asynchronous and is not necessarily identified with either distance or distributive models. ${ }^{16}$ There are two basic attacks leveled at the soundness of computer-mediated legal instruction. First, that it fails to deliver (and hence train) the professional face-to-face ${ }^{17}$ human interaction and socialization that underpin most of the necessary practice and professional relationship skills. ${ }^{18}$ Second, that after years of post-Langdellian experience we have arrived at the optimal method of legal education-a rigorous dialog that both exposes the analytical structure of law and simulates various practice experiences. ${ }^{19}$ Computer-mediated legal instruction is at best a poor, often clumsy way of creating effective interaction or dialog and, at

15. See, e.g., http://www.open.ac.uk/frames.html (last visited Feb. 18, 2001) (exemplifying use of distance education at The Open University). The United Kingdom's Open University has long incorporated a period of summer study and interaction at traditional learning institutions. See id. In addition, some "distance" models likely will include "boot camp" sessions for enrollees. See generally Clifford Adelmon, A Parallel Universe, CHANGE, May 1, 2000, at 2029 (describing growth of workshops and boot camps to prepare candidates for certification).

16. For example, the use of a PowerPoint or electronic whiteboard in an otherwise traditional classroom setting could involve some computer-mediation.

17. In a speech at Rutgers in the Fall of 1999, Justice Ginsburg reportedly stated "I am troubled by ventures like Concord ... I am uneasy about classes in which students learn entirely from home, in front of a computer screen, with no face-to-face interaction with other students or instructors." Mintz, supra note 9.

18. See, e.g., ABA Memorandum D9697-59, Distance Education, May 6, 1997 [hereinafter ABA Memorandum-Distance Education] (letter from James P. White, Consultant on Legal Education to the American Bar Association, to Deans of ABA-accredited law schools), available at http://abanet.org/legaled/distanceeducation/distance.html. White stated:

Educating a student for a Juris Doctor degree is professional education of a most distinct variety. It involves more than the mere delivery of information or simply learning facts, history or even logic. During a law school education a student is expected to participate in a learning community whereby he or she will ultimately learn, experience, and develop skills and knowledge that will advance the legal system, society and his or her career. This law school experience involves interaction with faculty not only in the classroom, but also in other places and at other times. Students also learn from each other by inquiry and challenge, review and study groups. In sum, law school is an educational process in which a Id. student matures with the law and his or her ability to use and develop it.

19. See generally Ruta K. Stropus, Mend It, Bend It, and Extend It: The Fate of Traditional Law School Methodology in the 21st Century, 27 Loy. U. CHI. L.J. 449 (1996) (arguing that law schools should fashion their curriculum based on virtues of Langdellian's method). 
worst (because of the lack of eye-to-eye contact), a fatal impediment to such valued educational conduits.

I believe that these arguments will have a short shelf life when faced with the reality of a world of e-services defined by our emerging business models and available technologies. First, it is arguable whether face-toface and community interaction any longer defines legal education. In part, this is because legal education itself will be forced to change to better train lawyers for electronically mediated careers and practices. It is also because we overestimate the law school time actually devoted to interaction (as opposed to, for example, independent study) and the quality of the interaction that actually takes place in our classrooms. ${ }^{20}$ Second, various species of computer-mediated and distributive learning techniques are already well-established in our law schools ${ }^{21}$ and have proven themselves, even in the hands of an as yet untrained professorate, to have both intrinsic worth and to facilitate better and more efficient traditional classroom interactions. Third, our idealistic (and occasionally self-serving) stance as to the correct way to teach law assumes that the next generation of our customers will share our interests and values-our belief in the inherent qualities of traditional legal education. In fact, an instant-messaging, multi-tasking applicant likely has a very different set of social and professional patterns, goals and desires, ${ }^{22}$ whether or not we agree with them. Coupled to this observation is the belief that these potential customers will at some time in the very near future defeat the inelastic demand model that law schools have relied on as they have allowed the cost of tuition to spiral up; ${ }^{23}$ a model that additionally may find itself challenged by a decline in the rewards of law practice. ${ }^{24}$

Bubbling under the criticisms of computer-mediated distance education are comparisons with or allusions to a previous experiment in legal $\mathrm{DE}$ - the correspondence school. ${ }^{25}$ Here, the comparison is not merely a

20. Again, I am indebted to Peter Martin's wisdom. For discussion of Martin's views on distance learning see infra note 77.

21. See generally Stephen M. Johnson, www.lawschool.edu: Legal Education in the Digital Age, 2000 WIS. L. Rev. 85 (2000) (discussing potential future for technology in legal education).

22. See, e.g., Stanford Institute for the Quantitative Study of Society's "Internet Study" (Feb. 16, 2000) (studying social consequences of Internet use), at http:// www.stanford.edu/group/siqss/Press_Release/press_release.html. The study includes the following two key findings: 1) people spend more hours on the Internet the more years they have been using it; and 2) up to a quarter of the respondents who use the Internet regularly (more than 5 hours a week) feel that it has reduced their time (in person or on the phone) with friends and family or attending events outside the home. See id.

23. For a further discussion of a tuition-free DE law school, see infra note 92 and accompanying text.

24. For a further discussion of the demand law school model, see infra note 159 and accompanying text.

25. For a critical and historical essay on correspondence schools, see David F. Noble, The Correspondence Course Goes Online: Comeback of an Education Racket, LE MONDE Diplomatique, Apr. 2000 (discussing history of distance education), availa- 
qualitative one, but an attempt to invoke and encourage a similar reaction from the historical (and legal) protectors of traditional law schools-accreditation bodies and state supreme courts.

As to the direct issue, any comparison of modern DE computer-mediated pedagogies with the old correspondence school model is scarcely credible. Modern DE delivers robust interactivity, includes synchronous elements, and enables far more varied content and compelling delivery. Further, the correspondence model became fatally disconnected from its orthodox competitors and the profession it sought to train for; in contrast, modern $\mathrm{DE}$ is closely related to the distributive education practiced in bricks-and-mortar law schools, and in tune with a practice environment heavily invested in information technologies.

There is a closer connection between the correspondence school and some pure-play DE law schools in their proprietary nature. It was overcommercialization that was at the heart of Abraham Flexner's famous critique of correspondence and vocational education in the 1920s. ${ }^{26}$ Such criticism resonates eerily as we examine the $\mathrm{DE}$ businesses that are emerg-

ble at http://www.monde-diplomatique.fr/en/2000/04/14noble. Therein, Noble notes the growth of correspondence schools within traditional higher education institutions as follows:

The evolution of correspondence instruction in the universities closely paralleled that of the commercial schools. It began in earnest in the 1890 s, and by the 1910 s and 1920 s it had become a craze comparable with today's passion for online distance education. Following the lead of the University of Chicago, other institutions joined in, notably the state universities of Wisconsin, Nebraska, Minnesota, Kansas, Oregon, Texas, Missouri, Colorado, Pennsylvania, Indiana, and California. By 1919, when Columbia University launched its home study programme, there were already 73 colleges and universities offering instruction by correspondence.

Id. Their decline is detailed as follows:

Before long, with a degraded product and a dropout rate almost comparable to that of the commercial firms, they, too, had come to depend for their survival on "drop-out money." At the end of the 1920s the university-based programmes began to come under the kind of scrutiny and scathing criticism hitherto reserved for the commercial schools. Abraham Flexner, one of the nation's most distinguished and influential observers of higher education, excoriated the American universities for their commercial preoccupations, for having compromised their independence and integrity, and for having thus abandoned their unique and essential social function of disinterested critical and creative inquiry.

Id.

26. See generally Abraham Flexner, Universities, American, English, German

(Oxford Univ. Press 1930). Specifically, Flexner remarked,

[I] $\mathbf{n}$ what terms is one to characterize the advertising of Chicago, Columbia, and other institutions which spread before thousands the alluring prospect of obtaining just as good an education . . . by mail? . . . The hopelessness of America lies in the inability and unwillingness of those occupying seats of intelligence to distinguish between genuine culture and superficial veneer, in the lowering of institutions which should exemplify intellectual distinctions to the level of the vendors of patent medicines.

Id. at 151-52. 
ing. ${ }^{27}$ It also raises one of the greatest challenges as we begin the process of re-engineering our institutions; we know that we must be more businesslike in our analysis and in the soundness of the value proposition we promote to our consumers, yet the academic, non-commercial nature of the law school enterprise is an integral part of the value proposition (at least from the perspective of the faculty and, hopefully, of the profession).

As to the second, indirect message aimed at regulators, the issue is more complex and raises the general issue of accreditation as an institutional impediment to the growth of legal DE. Historically, state supreme courts have controlled the grant of licensure. ${ }^{28}$ Those courts delegate competency and fitness testing and other administrative tasks to state boards of bar examiners. ${ }^{29}$ While it is only in the rare case of diploma privilege $\mathrm{e}^{30}$ that $\mathrm{ABA}$ accreditation directly affects bar admission, the majority of states ${ }^{31}$ require candidates for licensure to have graduated from an $A B A$ accredited law school, thus guaranteeing the indirect yet coherent impact of accreditation. ${ }^{32}$ The few states that are not fully synchronized with $\mathrm{ABA}$ accreditation generally require some alternate form of accredita-

27. See, e.g., Noble, supra note 25 (discussing commercial element in present distance education businesses). Noble goes on to state the following:

Like their forebears, today's proponents of distance education believe they are leading a revolution that will transform the educational landscape. Fixated on technology and the future, they are unencumbered by the sober lessons of this cautionary tale. If anything, the commercial element in distance education is this time even stronger. For now, instead of trying to distance themselves from their commercial rivals, the universities are eagerly joining forces with them, lending their brand names to Id. profit-making enterprise in exchange for a piece of the action.

28. For a primer in this area, see http://www.abanet.org/legaled/publications/Compguide2000, which sets forth comprehensive guide to bar admission requirements.

29. See, e.g., Mo. Sup. CT. R. 8 (providing responsibilities of Board Examiners in application process), available at http://www.osca.state.mo.us/SUP/index (last visited July 1, 2000).

30. Wisconsin has retained this system for its two accredited schools, the University of Wisconsin and Marquette University Law Schools. See, e.g., http:// www.courts.state.wi.us/bbe/Diploma_Privilege.html (last visited Feb. 18, 2001) (describing Wisconsin's system of diploma privilege).

31. For a summary of these states, see http://www.abanet.org/legaled/publications/compguide2000/cgchart3.

32. See, e.g., Mo. Sup. CT. R. 8.03(a)(2) (requiring candidates to graduate from ABA accredited law schools). Specifically, Rule 8.03(a) (2) states: "No person shall be eligible to take the bar examination until such person shall have: ... (2) [g] raduated with a Juris Doctorate degree from a law school approved by the American Bar Association . ...."Id.; $c f$. http://www.dcbar.org/about_bar/admissions.html (listing rules of District of Columbia requiring graduation of ABA accredited law schools). 
tion from a state educational agency ${ }^{33}$ or successful passage by rising firstyear students of a "mini-bar" examination. ${ }^{34}$

In practical terms, therefore, $\mathrm{ABA}$ accreditation ${ }^{35}$ is a sine qua non for an institution seeking to educate lawyers for the U.S. practice market. Moreover, $\mathrm{DE}$ providers, like the correspondence schools that went before them, will fail to meet the "bricks-related" accreditation standards ${ }^{36}$ dealing with residence requirements, ${ }^{37}$ physical plant ${ }^{38}$ and library resources. ${ }^{39}$ At the moment, pure-play ${ }^{40} \mathrm{DE}$ schools will be denied ABA accreditation, and thus their graduates will generally be disqualified from

33. See, e.g., Colo. Sup. CT. R. $§ 201.5$ (2) (a) (ii) (allowing candidate to qualify to take state bar exam by obtaining professional law degree for state accredited law school), available at http://www.courts.state.co.us/ble/Rules.html; Rules Regulating Admission to Practice Law in California, Rule VII, Sec. 2(b) (Jan. 1, 1997) (listing alternative legal education requirement that allows candidate to take bar exam), available at http://www.calbar.org/shared/2admrule.htm. Thus, Concord University School of Law graduates are eligible to take the California bar as Concord is registered with the Committee of Bar Examiners of the State Bar of California and approved by the State's Bureau for Private Postsecondary and Vocational Education. See Becoming an Attorney, at http://www.concordlawschool.com/careerplanning.htm (last visited Feb. 18, 2001) (describing process of becoming attorney in California for Concord law students).

34. See, e.g., http://www.abanet.org/legaled/publications/Compguide2000/ cgchart3 (noting that California allows students who "passed a law students' examination administered by the examining committee after completion of his or her first year of law study" to qualify to take bar exam).

35. See generally ABA, The American Bar Association's Role in the Law School Accreditation Process (1997) (discussing accreditation process for law schools), available at http://www.abanet.org/legaled/accreditation/abarole.html.

36. See Standards for Approval of Law Schools, Ch. 3, Standard 304(g) [hereinafter ABA Standards] (addressing credit for study by correspondence), available at http://www.abanet.org/legaled/standards/chapter3.html (last visited Feb. 18, 2001). Standard 304(g) explicitly deals with correspondence schools and DE as follows: " $(\mathrm{g})$ A law school shall not grant credit for study by correspondence. A law school may grant credit for distance learning study in accordance with such temporary or permanent guidelines as are authorized by Council." Id.

37. See id. Standards 304-05 (setting out course and residency requirements).

38. See ABA Standards, Ch. 7, Standards 701-03 (requiring physical facilities and technological capabilities, such as library and study space), available at http:// www.abanet.org/legaled/standards/chapter7.html (last visited Feb. 18, 2001).

39. See ABA Standards, Ch. 6, Standards 601, 606 (setting forth law library's requirements), available at http://www.abanet.org/legaled/standards/chapter6.html (last visited Feb. 18, 2001). Physical space standards aside, DE providers likely would have problems meeting faculty-student rations. See ABA Standards, Interpretation of Standard 402 (setting forth requirements that law schools have certain ratio of full-time students to full-time faculty), available at http:// www.abanet.org/legaled/standards/chapter4.html (last visited Feb. 18, 2001).

40. "Pure-play" is a term used in e-commerce to describe a business model that is executed solely in virtual space rather than partly in real space and partly in virtual space. Thus, Amazon.com is a pure-play model, while Barnesandnoble.com, closely related to the bricks-and-mortar stores with which it shares its name, is a "click-and-brick." Some bricks-and-mortar institutions consciously distance themselves from their pure-play corporate cousins, such as WingspanBank.com (http://www.wingspanbank.com), which is a division of the "traditional" BankOne (http://www.bankone.com/). 
state bar licensure. Meanwhile, accredited institutions will be permitted to convert to very limited click-and-brick models subject to the "Temporary Distance Education Guidelines."41

Of course, one person's legitimate educational goal may be another's illegal agreement to protect or divide a market. ${ }^{42}$ Arguably, the bricksrelated standards both create barriers to entry for low-cost, web-based players and deter existing accredited schools from providing services outside their geographic markets. ${ }^{43}$ Obviously, a "quality" argument is at its strongest when accredited education is no more expensive than that provided by a litigation-minded unaccredited school. ${ }^{44}$ Yet as DE providers

41. See ABA Memorandum - Distance Education, supra note 18 (setting forth approved temporary guidelines for distance education).

42. There is near unanimity that the Sherman Act applies to educational accreditation. For example, one reference states that

[a]ll the possible objectives of antitrust law- from efficient resource allocation, minimum production costs, and maximum innovation to equal access to the market and "fair" distribution according to competitive standards-can implicate the activities of nonprofit organizations. If the behavior is anticompetitive, the consequences are equally detrimental whether or not the actor pays dividends to its owners. In addition, many nonprofit firms represent or compete with for-profit firms .... For these reasons, virtually all courts hold that a firm's non-profit status confers no exemption from the antitrust laws ....

Phillip Areeda \& Herbert Hovenkamp, Antitrust Law 1 261 (1997). See generally Found. for Interior Design Educ. Res. v. Savannah Coll. of Art \& Design, 73 F. Supp. 2d 829, 834-35 (W.D. Mich. 1999) (discussing denial of accreditation as possible anti-trust law violation); Andy Portinga, Note, ABA Accreditation of Law Schools: An Antitrust Analysis, 29 U. MiCH. J.L. REFORM 635, 641-53 (1996) (discussing applicability of anti-trust laws in context of ABA accreditation activities). Any contrariness is traceable to the well-known excerpt from Marjorie Webster Junior Coll. $v$. Middle States Ass'n of Colleges $\mathcal{E}$ Secondary Schools, Inc., in which the court stated the following:

[T] he proscriptions of the Sherman Act were 'tailored ... for the business world,' not for the noncommercial aspects of the liberal arts and the learned professions. In these contexts, an incidental restraint of trade, absent an intent or purpose to affect the commercial aspects of the profession, is not sufficient to warrant application of the antitrust laws.

432 F.2d 650, 654 (D.C. Cir. 1970) (footnotes omitted).

43. See George B. Shepherd \& William G. Shepherd, Scholarly Restraints? ABA Accreditation and Legal Education, 19 CARDOZO L. REv. 2091, 2150 (1998) (discussing negative affects of $\mathrm{ABA}$ accreditation). The authors state that

[ $t$ ] he ABA's prohibition on correspondence courses has a similar anticompetitive economic impact as an agreement among producers of any good to split geographic markets: the same impact as Coke and Pepsi agreeing that Pepsi would sell only to the east of the Mississippi, and Coke would sell only to the west. Such an agreement creates a monopoly Id. in each region over consumers who are unwilling or unable to travel.

44. See, e.g., ABA President Anderson Responds to Newspapers Editorials, Oct. 1, 1998 (responding to columns such as Thomas Sowell, Tin Gods Happiest Playing with Lives, ARIz. RePUBLIC, Sept. 25, 1998, at B7, which criticizes ABA's accreditation process), available at http://www.abanet.org/legaled/aba_president_ander son_responds.html. 
extract costs from the legal education system ${ }^{45}$ and attract state agency or national DE accreditation, ${ }^{46}$ the bricks-and-mortar schools' antitrust arguments will weaken. ${ }^{47}$ The political climate also will change in favor of the pure-play providers as general $\mathrm{DE}$ becomes familiar and attracts investment. If access to affordable legal education becomes a credible slogan of $\mathrm{DE}$ providers, it will not take long for some state supreme courts to break ranks on the issue of $\mathrm{ABA}$ accreditation.

\section{UbiQuity AND the Information Age}

Comprehension of the underlying technologies is important for a number of reasons impacting the evolution of legal education discussed herein. The characteristics of the enabling technologies and their potential deployment in the law school context contribute to the debate over the quality of computer-mediated, distance and distributive learning, while the availability and performance of the infrastructure and appliances speak volumes about the expectations of future legal education customers, the changing legal practice paradigms, and the demands to be placed on the legal system that must be predicted by the teachers of the next generation of lawyers.

The Internet is not a single, undifferentiated technology. From the perspective of early 2000, it appears that the second decade of the Information $\mathrm{Age}^{48}$ will be defined by two core technologies-wireless and broadband- and two themes-globalization and convergence. Together, all of these work towards the new Internet paradigm-ubiquity.

45. Concord's tuition ( $\$ 4,800$ per year) is approximately one fourth of what a traditional private law school and one- half what a public school would charge. See Tuition and Fees (stating Concord tuition), available at http:// www.concordlawschool.com/admissionstuition.htm (last visited Feb. 18, 2001)); see also Tuition Information (stating that tuition for California resident to attend Boalt Hall at University of California-Berkeley is $\$ 10,804.50$ per year), available at http://www.law.berkeley.edu/admissions/tuition.shtml (last modified May 30, 2000); Admissions Information (noting tuition for Stanford Law School as private university is $\$ 27,726$ per year), available at http://lawschool.stanford.edu/admissions/admiss.shtml (last visited Feb. 18, 2001).

46. The Distance Education and Training Council has accredited Concord University. See generally Nation's First Online Law School Receives DETC Accreditation, Excite News, Jan. 20, 2000 (discussing accreditation of Concord University School of Law); see also http://www.concordlawschool.com/schoolinfodetc.htm (same).

47. Many of the issues discussed herein were left unresolved in the consent decree between the ABA and the Justice Department relating to faculty compensation, proprietary schools and transfers of credit from state accredited schools. See United States v. ABA, 934 F. Supp. 435, 435-39 (D.D.C. 1996) (listing conditions contained in consent decree).

48. Throughout this Essay, I will refer to the first two decades of the Information Age. The first decade is viewed as 1990-2000. Although the end of that decade marked the thirty-year anniversary of ARPANET, the last decade of the twentieth century saw the beginning of the web. Identifying the web's birth is not a simple or uncontroversial task. However, one contending date would be the Fall 1993 release of the Mosaic web browser. Thus, in this Essay the period 2000-2010 is referred to as the second decade of the Information Age. 
The network we are building is a global one. Half the U.S. population now has net access, and a half-billion people will be online worldwide by $2003 .{ }^{49}$ The Internet of 2000 is a phenomenon of the industrialized world and United States-centric in its cultural and economic perspectives. The network that is under construction, however, is a global one, and the second decade of the Information Age will essentially see us "wire" the entire planet. We will see massive activity in currently "under-wired" developed countries featuring a combination of wireless technologies, and the rethinking of traditional barriers not present in the U.S. infrastructure such as telephone company charges for local connect calls (that are unmetered in the United States)..$^{50}$

Except in underdeveloped regions ${ }^{51}$ and, perhaps counter-intuitively, in a few highly developed countries, ${ }^{52}$ basic infrastructure will continue to be hardwired, albeit continually upgraded to provide additional bandwidth. However, wireless infrastructure will increase exponentially when it comes to getting the data to consumers (the last mile or halfmile). Most of the next generation of web appliances will be wireless and by the end of the next decade the majority of communications will be wireless. ${ }^{53}$ Many of this generation's portable devices (e.g., PDAs and mobile phones) will take on additional wireless network functions and most

49. See generally Progressive Policy Institute, Online Population (Dec. 1998) (describing percentages of persons with internet access), available at http:// www.neweconomyindex.org/states/party_pagel.html.

50. See, e.g., Robert Zeithammel, German ISP to Introduce Flat Fee, CNET NEws.COM, Feb. 24, 2000 (discussing move away from charging customers for every minute of Internet access), available at http://news.cnet.com/news/0-1005-2001557391.html; http://www.timetobreathe.net/breathe/join.html (offering free ISP services in United Kingdom); http://www.ntlworld.com/signup/index.html (offering free Internet access in United Kingdom). Free or low-cost services have dramatically effected web demographics in England, increasing the number of persons with web access to thirty percent. See UK Internet Use Surges, BBC News ONLINE, May 26, 2000 (citing low costs as reason for surge), available at http:// news.bbc.co.uk/hi/english/business/newsid_765000/765024.stm.

51. See David Jang et al., Electric Word, WIRED, Jan. 2000 (discussing use of wireless local loop, pagers and wireless pay phones for personal telecom service in Tanzania and Ghana), available at http://www.wired.com/wired/archive/8.01/ eword.html.

52. See generally Peter H. Lewis, Wireless Valhalla: Hints of the Cellular Future, N.Y. TIMEs, July 13, 2000, at G1 (discussing growth of wireless communications in Nordic countries).

53. According to IDC, the number of wireless device users with access to inbound and outbound information services and Internet messaging will increase a whopping 728 percent from 7.4 million in 1999 to 61.5 million by 2003 in the United States. See Wireless Internet to Surpass PC Internet, NUA INTERNET SurveYs, Feb. 10, 2000 (discussing trends in wireless market), available at http:// www.nua.net/surveys/index.; see also Japan's Web Phone Revolution, BBC News ONLINE, May 23, 2000 (noting that "[t] he mobile phone is set to overtake the computer as the most popular way to access the internet in Japan"), available at http:// news.bbc.co.uk/hi/english/world/asia-pacific/newsid_760000/760392.stm. 
appliances and devices will also communicate wirelessly inter se. ${ }^{54}$ Obviously, such technologies provide the convenience of portability. Nonetheless, the connectivity, and indeed the interconnectivity, goes further. It removes the physicality from the Internet experience, to truly make the experience (and the commerce) ${ }^{55}$ virtual. ${ }^{56}$

Corporate and academic users have long enjoyed Internet connectivity through networks and high-speed digital data lines. "Broadband" refers to the provision of high-speed Internet access to homes and small businesses by transmitting digital signals along wires that, typically, were designed for and are still utilized for analog transmissions (e.g., telephone company and cable TV local wiring). High-speed, in this context, means higher than the modem speed enjoyed by SOHO users during the first decade of the information age. ${ }^{57}$ In the United States, 1.4 million households had broadband access at the beginning of 2000.58 That number will exceed 16 million by $2004 . .^{59}$ More importantly, for those whose ideas of growing the educational space have egalitarian aspects, the growth in broadband access will be heavily biased towards urban areas. Rural districts will lag seriously behind in the race to re-wire America. ${ }^{60}$

Broadband or higher-speed connections will bring more speed which will help drive convergence technologies such as (over-hyped) interactive TV and (revolutionary) PDA/mobile phone-based e-mail and browsing. Until we have fiber networks connected directly to our homes and small businesses (known as the "last mile" issue), even broadband speed will not be fast enough for broadcast-quality video, but it will support lower quality, highly compressed streamed media and desktop video applications. ${ }^{61}$ Im-

54. See generally BLUETOOTH wireless technology (describing Bluetooth wireless technology which provides $2.45 \mathrm{GHz}$ two-way data speeds of up to $1 \mathrm{Mbps}$ at range of 10 meters), at http://www.intel.com/mobile/bluetooth (last visited Feb. 18, 2001).

55. See, for example, the Televend, Inc. website, http://www.tele-vend.com, which provides wireless technology, that allows the user to use his or her cell phone for commercial purposes.

56. See generally Pierre Lévy, Becoming Virtual: Reality in the Digrtal Age (1998) (describing human-computer interaction and virtual reality).

57. In practice, both current broadband technologies bring data in at around 500 kilobytes per second, more than ten times the speed of a conventional 56K modem that typically operates in the $\mathbf{4 0}$ kilobytes-per-second range.

58. See Seth Schiesel, Broadband: How Broadly? How Soon?, N.Y. Times, Jan. 17, 2000 , at $\mathrm{Cl}$ (noting that, of this figure, 1.1 million used cable lines while 300,000 used phone lines).

59. The Yankee Group Forecasts 16.6 Million High-Speed Internet Homes by 2004, YANKEE Group, Jan. 28, 2000 (discussing market for residential high-speed Internet access), at http://www.yankeegroup.com/webfolder/yg2la.nsf/press/91387 142EAE68640852568740049000B?OpenDocument.

60. For a discussion of how America will be rewired, see infra note 228 and accompanying text.

61. A channel of compressed high quality video requires at least two to five megabytes of bandwidth. Few broadband installations consistently provide more than $500 \mathrm{~K}-1 \mathrm{MB}$ bandwidth. 
portantly for educationalists and "distance" marketers, it will also support robust net meeting and streaming video technologies. Far more important than speed, however, is the persistent connection that is part of these technologies. ${ }^{62}$ This "always on" feature will spawn new Internet services such as Application Services Providers (ASPs) that will provide "just-intime" software, plug-ins and "rental" software or, in the click-and-brick law school context, automatically updated courseware.

As befits a nervous system, our points of contact with the net will be many and varied. ${ }^{63}$ Most obviously, the next generation of our current information-retrieval devices will be considerably more sophisticated and flexible. At first, these devices may be relatively pedestrian Wireless Application Protocol ("WAP") products that do wirelessly what we do with wires today. ${ }^{64}$ The products and services will evolve more fully, however, as current $\mathrm{PC}$ functions are disaggregated and innovation seeps in to device technology. ${ }^{65}$

When combined, global networking, convergence, broadband, wireless and persistence translate into ubiquity. Simply put, the Internet will be everywhere. More than just physically being "there," it will be psychologically "there" and accepted, even familiar. As such, the network will be taken for granted, as many have remarked, like electricity or underwear. It is this ubiquity that will best define Internet space in the second decade

62. The persistent connection is otherwise known as the "new" $24 \times 7$. paradigm.

63. See Peter H. Lewis, Look Out! New Wrist Devices on the Loose!, N.Y. Times, Jan. 20, 2000, at D1 (discussing wrist watch devices that, depending on design, "double as cell phones, one-way pagers, e-mail readers, computers, cameras, MP3 music players, television receivers, voice recorders, automobile security keys, television and VCR remote controls, health monitors, weather stations, compasses, Global Positioning System monitors, altimeters, games and simple amusements"), available at http://www.nytimes.com/library/tech/00/01/circuits/articles/20watc.html.

64. See WAP Forum (devoting webpage to providing information concerning world standard for wireless information and telephone services on digital mobile phones and other wireless terminals), at http://www.wapforum.org (last visited Feb. 18, 2001); see also Openwave Systems, Inc. (providing example of United States product), at http://www.phone.com/index.html (last visited Feb. 18, 2001). A good example of the services that will appear in the U.S. space is the Japanese market "i-mode" service, featuring "always on," mobile phone-based web and voice services. See generally DoCoMo Net (providing information on and access to imode), at http://www.nttdocomo.com (last visited Feb. 18, 2001); see also Thalia (selling technology that allows appliances to "talk" to one another), at http:// www.thaliaproducts.com/intro.html (last visited Feb. 18, 2001).

65 . Concurrent with this technology will be the networking of existing technologies or appliances such as automobiles, microwave ovens and refrigerators so they will become smarter (i.e., dispense updated information) and they will enable new web-based services, thus becoming e-pliances. See Andy Reinhardt et al., The Soul of a New Refrigerator, Bus. WK., Jan. 17, 2000, at 42 (discussing new e-pliance refrigerator); David Lammers, Smart Appliances Hit the Net, EE TimEs, Jan. 18, 2000 (discussing movement toward e-pliances), at http://www.techweb.com/wire/ story/TWB20000118S0032. 
of the Information Age. In what is sometimes referred to as the post-PC world, everyone and everything will be networked. ${ }^{66}$

These trends will revolutionize a law school space that heretofore has been linked immutably to a specific geographic location. Virtual law school communities will be persistent, and membership in a virtual community can coincide or overlap with membership in a real space legal community. Equally, legal information, the data that fuels our classes and discussions, will no longer be fixed in time or space, but rather will be continually updated in real time and available anytime and everywhere.

\section{Education Space and E-Services}

The pre-web Internet was a research and educational domain. Thereafter, the first decade of the information age was dominated by the distribution of pornography, various advertising or marketing models, and the web-enabled sale of hard goods. ${ }^{67}$ During the second decade, the Internet will once again be transformed, this time by the sale of digital goods and the rapid relocation of most business-to-business ("B2B") and business-to-consumer ("B2C") services to the web.

Thus, it is a mistake to frame the distance learning issue in purely law school terms. The e-service market that is exploding into the economy impacts not only law school space or even legal educational space, but also the general educational space. ${ }^{68}$ Of course, the e-service activities of individual law schools will continue to affect the internal market (e.g., law school A's distance program causes B's real space enrollment to drop). Despite the impact from these individual law schools, it is the decisions, strategies, content and relationships from the broader educational space that may have the most fundamental impact on law school space. This should not be viewed as necessarily negative for the traditional law schools. We may not be facing a zero-sum game. ${ }^{69}$ Technology, investment and demographics mean that the combined bricks-and-mortar and virtual educational space paradigm will likely expand compared to today's pure bricks-and-mortar model. ${ }^{70}$ Furthermore, even legal educational space will grow, and law school space may expand at the expense of other programs, such as undergraduate law or business school courses. That space

66. See generally Lisa DiCarlo, Fionino: How We'll 'Warm' the Web, EWEEk, Nov. 16, 1999 (describing Hewlett Packard CEO's vision of world in which everything people use is networked), at http://www.zdnet.com/zdnn/stories/news $/ 0,4586$, 1018157,00.html.

67. See e.g., http://www.Amazon.com (selling books and music).

68. See generally Developing a Distance Education Policy for 21st Century Learning, Am. CounciL on Educ. (Mar. 2000) (discussing how technology will impact distance education), at http://www.acenet.edu/washington/distance_ed/ 2000/03march/distance_ed.html.

69. See Philip Evans \& Thomas E. Wurster, Blown to Brts 6 (2000) (suggesting that virtual educational space will aid traditional bricks-and-mortar space).

70. For a discussion of demographics, see infra note $\mathbf{7 4}$ and accompanying text. 
will, however, be populated by different or reorganized players at the expense of the autonomy currently enjoyed by law schools, both individually and collectively.

Legal education space should be attractive to those selling distance learning and related services. The customer base will have good demographics, therefore making advertising and cross-marketing deals more attractive. Juris Doctor candidates, like other graduate students, will be more interested in part-time education; they are likely to have pre-existing job skills and opportunities and will no longer be as interested in the fraternity housing and Division I sports central to the bricks-and-mortar institution. Moreover, from the distance learning business's perspective, adding a postgraduate/professional layer to its undergraduate site involves only marginal costs.

Notwithstanding, some aspects of legal education space make it less attractive as an e-business. First, it is dominated by large, established publishing brands that provide content and some distributive learning tools. Second, it centralizes many key functions (e.g., faculty hiring, conferences, professional development) in its trade association. ${ }^{71}$ Third, legal education has robust accreditation standards and procedures that likely will require judicial scrutiny. ${ }^{72}$ Finally, it is a market that is heavily output sensitive; legal education space has a conservative market for its graduates (very different from an online computer science graduate, who may be more easily "sold" to a dot.com).

Beyond difficulties in mapping legal education to e-service paradigms, ${ }^{73}$ the emergence of legal DE may also be slowed by the strength of the traditional educational model as it benefits from the next population bulge $^{74}$ and a likely incremental growth in law school admissions that reflects a healthy economy and a demand for IP and e-commerce-enabled associates.

It must also be appreciated that consumer and capital enthusiasm for things virtual does not evolve in a linear fashion. After participating in the dramatic growth of e-commerce at the end of the millennium, consumers

71. See, for example, The Association of American Law Schools webpage, providing a single source for information on hiring, conferences and workshops, at http://aals.org.

72. For a discussion of legal accreditation standards, see supra note 28 and accompanying text. ing text.

73. For a discussion of e-service paradigms, see infra note 96 and accompany-

74. See generally Califormia Expects a 36\% Increase in College Enrollment by 2010 , Chron. Higher Educ., Sept. 21, 1999 (discussing how college enrollments are confidently expected to increase over next decade due in large part to population growth). The number of persons in the traditional law school age group also are higher, at least for the first half of the next decade. See David Leontlardt, Battle of the Graduate Schools, Law Gains Edge on Business, and No One Knows Why, N.Y. TIMEs, July 5, 2000, at $\mathrm{Cl}$ (noting 3\% increase in law school applications for fall 2000, which is second consecutive increase). 
themselves may trigger a pause as they rethink their enthusiasm for various real and virtual commerce models. Similarly, the capital market, particularly as represented by venture capitalist funds, likely will experience shifting patterns of enthusiasm for web businesses, particularly B2C models. ${ }^{75}$

Such factors or concerns may slow the rate of growth of legal DE into the markets heretofore exclusively enjoyed by bricks-and-mortar law schools. Even given the worst scenario for the penetration of $\mathrm{DE}$, however, bricks-and-mortar schools will experience a significant impact on enrollment. DE will provide the most attractive alternative for part-time students, and schools with part-time divisions (that tend to use subsidies from part-time divisions to support other parts of the program) will suffer disproportionately. ${ }^{76}$

One of the mysteries of nascent legal distance learning is identifying the major "players." Within law school space we will see some institutions move forward aggressively; however, they will be positioning themselves for partnering more than direct market domination. The same is probably the case with the existing legal education publishers. ${ }^{77}$ The total legal educational space is far larger than the law school J.D. space, including LL.M.'s, ${ }^{78}$ bar review ${ }^{79}$ and CLE providers. Thus, proprietary online J.D. schools, ${ }^{80}$ such as Concord, ${ }^{81}$ must be seen as part of far broader strategies to provide online legal education and services. ${ }^{82}$ It should also be noted that, during the next few years, it is likely that two or more players

75. See, e.g., Jonathan Rabinovitz \& Mark A. Mowrey, IPO Market Unravels, StANDARD, May 19, 2000 (noting cooling-down of IPO market), available at http:// www.thestandard.com/article/display/0,1151,15293,00.html; see also Bob Tedeschi, Digital Darwinism Hits Online Toy and Craft Stores, N.Y. Trmes, May 29, 2000, at C5 (noting slow down on investment in Web merchants), available athttp:/ /www.nytimes.com/library/tech/00/05/cyber/commerce/29commerce.html.

76. See Law School Attendance, ABA (Fall 1999) (stating that United States-accredited law schools conferred 39,071 degrees in 1999 of which 5063 (or 12.9\%) were to part-time students), at http://www.abanet.org/legaled/miscstats.html.

77. See generally Peter W. Martin, The Internet: "Full and Unfettered Access" to LawSome Implications, 26 N. Ky. L. REv. 181 (1999) (providing comments made by Professor Peter Martin of Cornell Law School made during his presentation at Distance Learning Workshop sponsored by ABA Section on Legal Education in Indianapolis on November 20, 1999 that legal education publishers will also partner).

78. For a listing of various L.L.M. distance learning programs, see Gradschools.com, which is available at http://www.gradschools.com/listings/distance/ laws_master_distance. html.

79. See, for example, Bar Bri website which provides courses devoted to the bar review at http://www.barbri.com.

80. For a listing of online law schools, see Gradschools.com, at http://www. gradschools.com/listings/distance/law_distance.html.

81. See Concord University School of Law [hereinafter Concord] (providing online J.D. program), at http://www.concord.kaplan.edu (last visited Feb. 18, 2001).

82. See, e.g., Sarah Carr, Kaplan to Offer Advanced-Placement Preparation Courses Online, Chron. Higher Educ., Mar. 2, 2000 (discussing Kaplan's plans to offer 
will emerge as the dominant vertical portals serving the legal market. ${ }^{83}$ These portals will need content, interaction and cross-marketing opportunities, and will likely look to legal education as a source. What is as yet opaque is whether anticipated popular demand for legal literacy will translate into a genuine opportunity for sophisticated legal education or simply a web-enabled, "law-for-dummies."

In general education space, the well-known higher education brand names, ${ }^{84}$ or joint ventures, ${ }^{85}$ and some pure-play brands ${ }^{86}$ are already staking out their positions. Many universities already have relationships with distributive learning providers ${ }^{87}$ and will likely move even further by partnering with distance specialists. ${ }^{88}$ Somewhat ironically for a cyberworld that treats disintermediation as quasi-religious, the technology allows for whole new industries of intermediaries or information brokers; these, too, are likely to become serious players in education space. ${ }^{89}$ It should also be remembered that DE essentially is a server-side technology. While the major technology companies continually eschew interest in vertical integration into content, they are interested in tying up the technol-

advanced placement preparation courses online), available at http://chronicle.com/free/2000/03/2000030201u.htm.

83. See, e.g., Law.com (serving legal market), at http://www.law.com.

84. See Goldie Blumenstyk, University of Cambridge to Collaborate with a Media Giant on an Online M.B.A., Chron. Higher Educ., July 17, 2000 (discussing Cambridge's initial steps to develop distance education with executive M.B.A.), available at http://chronicle.com/free/2000/07/2000071701u.htm; Sarah Carr, A For-Profit Subsidiary Will Market Cornell's Distance Programs, Chron. Higher Educ., Mar. 14, 2000 (discussing Cornell's plans to create for-profit subsidiary to establish and market distance learning program), available at http://chronicle.com/free/2000/03/ 2000031401u.htm; Sarah Carr, Faculty Members Are Wary of Distance-Education Ventures, Chron. Higher Educ., June 9, 2000 (discussing Cornell faculty's views on University's distance learning program), available at http://chronicle.com/free/ v46/i40/40a04101.htm.

85. .See, e.g., Fathom (representing for-profit joint venture consisting of Columbia University, London School of Economics and Political Science, Cambridge University Press, British Library, Smithsonian Institution's National Museum of Natural History, New York Public Library, University of Chicago, American Film Institute, RAND and Woods Hole Oceanographic Institution), available at http:// www.fathom.com/; see also Sarah Carr, 3 Universities May Jointly Offer Online Courses to Alumni, Chron. Higher Educ., Mar. 1, 2000 (discussing proposed joint venture between Princeton, Yale and Stanford), at http://chronicle.com/free/2000/03/ 2000030101u.htm.

86. See, e.g., Jones International University (representing first fully online-accredited university), at http://www.jonesinternational.edu/.

87. See, e.g., WebCT.com (representing distributive learning provider), at http://www.webct.com.

88. See, e.g., eCollege.com (specializing in distance education), at http:// www.ecollege.com; Unext.com (same), at http://www.unext.com; Smartplanet.com (offering courses in computing and business), at http:// www.smartplanet.com/sphome.asp.

89. .See, e.g., Embark (acting as intermediary for education), at http:// www.embark.com. 
ogy associated with educational space. ${ }^{90}$ In addition, the disdain for vertical integration does not seem to be shared by the major media companies. ${ }^{91}$ Finally, the new web economy is capable of nurturing radically new models and, hence, providers. For example, the legal education for tuition-for-fees paradigm is not unassailable. With costs properly extracted, a judicious use of advertiser support ${ }^{92}$ and robust cross-marketing, it might well be possible to offer tuition-free distance education. ${ }^{93}$

Many positives can result from the investment and technological innovations that we will see in education and legal education space. As with general educational space, the offering of such services on the web will increase (initially at least) the market for legal educational services. Also, on the web we will likely see different aggregations of service providers. For example, business school law courses and CLE type courses may well be aggregated in virtual space, although they seldom overlapped with traditional law school educational space.

The winners in legal education space will be determined by critical mass. Successful players will attract partners and venture capital, and aggregation will follow. This is not a time to be timid, to keep silent and hope the technology will settle somewhere else. The future of law school education is riding on gaining access to this investment and technology. If law schools resist this technology, if they do not lead, but attempt to cartel the change, they, and eventually the law they have nurtured, will be marginalized.

90. See Justine Kavanaugh-Brown, MIT Opens Its Gates, Gov't TECH., Feb. 2000 (discussing how MIT and Microsoft have launched joint research project to advance technology in education), available at http://govt-tech.govtech.net/publications/gt/2000/feb/education/education.shtm.

91. See Steve Lohr, Media Megadeal: The Strategy; Medium for Main Street, N.Y. Times, Jan. 11, 2000, at Cl (discussing how AOL-Time Warner merger represents triumph of Internet as force in business and viable medium for main street America).

92. Essentially, the business model would involve the DE business "delivering" a high demographic future customer to specific advertisers. Assume, for the sake of argument, that a properly scaled DE could deliver a two-year J.D. program for $\$ 1,000$ per student. Assume further that advertising and cross-marketing delivered during the program would reduce that sum to $\$ 700$ per student. The question would then be whether an advertiser or groups of advertisers would pay $\$ 700$ to have that J.D. delivered to them upon graduation.

93. See Lisa Guernsey, Education: Web's New Come-On, N.Y. Times, Mar. 14, 2000 , at D1 (discussing how e-commerce sites are now seeing online courses as way to lure shoppers), available at http://www.nytimes.com/library/tech/00/03/circuits/articles/ 16sell.html; see also Cindy Loose, Online Education to Be Free, WASH. Post, Mar. 15, 2000, at Al (discussing down payment of $\$ 100$ million by billionaire toward creation of online university offering ivy-league-quality education to anyone in world), available at http://www.washingtonpost.com/wp-dyn/articles/A94022000Mar14.html; Reuters, 2 Net Concerns to Form Online University, N.Y. TIMEs, May 31,2000 , at C8 (noting link between Barnesandnoble.com and Notharvard.com to provide free online education as sales and marketing tool). 


\section{Filling Law School Space}

Law schools throughout the country have now adopted a corporate approach to providing information technologies, and the growth of corporate-like services will (indeed, must) continue. Schools have recast themselves as technology providers supplying students with ISP and networking services. They have invested heavily in web marketing and are building sophisticated integrated information environments to facilitate administrative computing. A large proportion of faculty-student communications is now electronic, primarily through e-mail. Compared to the Kingsfieldian picture of Mrs. Nottingham guarding access to her boss, clearly we have come a long way. Survival, let alone success, in a world of e-services will demand much more of us. ${ }^{94}$

Mature e-commerce spaces are defined by their infrastructure and then filled by appliances and e-services. ${ }^{95}$ Our hybrid and relatively immature law school space is still debating many of its core technology choices while struggling to comprehend e-service (or in some cases, any) business models. Initially, therefore, legal education must face two fundamental, interlinked questions; first, what are the options for filling law school space, and second, what will be the key attributes of the model most likely to initially dominate that space-the click-and-brick hybrid?

\section{A. E-Commerce Models and Law School Space}

As discussed above, the U.S. law school market possesses certain characteristics that might hinder its absorption into modern business constructs. ${ }^{96}$ Still, additional issues must be addressed when those suggested models are from the world of e-commerce. E-commerce models based around marketing or sales of goods are relatively easy to conceptualize, as they tend to track existing real space models and relationships. There are aspects of law school space that fit within these models. However, at its roots, education is a service, and e-service models are varied and more complex to analyze than other e-commerce models. Models or species of e-commerce aside, it is important to recollect the key features that drive ecommerce ventures. The Internet excels in reducing information and transaction costs. ${ }^{97}$ As to the former, e-service models will be offered that

94. Kingsfield's secretary was finally identified by name in the TV series. She was played by Betty Harford. My thanks to my colleague Mike Nevins for his encyclopedic knowledge of such things.

95. See generally DiCarlo, supra note 66 (discussing Hewlett Packard CEO Carly Fiorina's 1999 Comdex keynote).

96. For a discussion of possible obstacles to applying modern business constructs to law schools, see supra notes 71-72 and accompanying text.

97. See Evans \& Wurster, supra note 69, at 13 ("Information is the glue that holds value chains and supply chains together. But that glue is now melting. The fundamental cause is the explosion in connectivity and in the information standards that are enabling the open and almost cost-free exchange of a widening universe of rich information."). 
dramatically challenge and inevitably destabilize the traditional law school structure. As to the latter, clearly law school space will be assaulted with more efficient marketing by and of law schools.

The pure-play model that has received the most attention is the fully online law school, pioneered and typified by Concord. ${ }^{98}$ This is essentially a broadcast (or one-to-many) model. ${ }^{99}$ Such a model extracts costs from the business of legal education by dispensing with the "retail space" of the traditional law school and using a heavily leveraged teaching model 'for example, by replacing expensive tenure-track law professors carrying a research overhead with instructors or by having teams of instructors working at the behest of more traditional faculty). ${ }^{100}$ Revenue then becomes a function of an infinitely variable and scaleable enrollment. Near term, this is the model toward which accreditation agencies will be most hostile. ${ }^{101}$ This model's inputs could be quite strong if its value proposition becomes clear in untapped and part-time markets. ${ }^{102}$ The model's Achilles heel will be in outputs, at least while hiring partners are still graduates of traditional law schools.

The one-to-many broadcast model, however, is but one example of the e-businesses that will seek to fill law school space and challenge the hegemony of existing bricks-and-mortar schools. At the B2B level, bricksand-mortar, click-and-brick and pure-play law schools will all likely purchase content from syndicators ${ }^{103}$ and outsource admissions, $\mathrm{DE}$ and other functions by using procurement sites. ${ }^{104}$

At the $\mathrm{B} 2 \mathrm{C}$ level we will see content aggregators grouping practice, CLE and law school content from multiple sources and in varied for-

98. See generally Concord, supra note 81 (hosting fully online law school), at http://www.concord.kaplan.edu/. Of course, Kaplan Inc. is a real-world, test preparation company and publisher. It may well be that their business model also is a click-and-brick model, but the Concord "click" was built first. See Goldie Blumenstyk, Expanding Its Reach in Higher Education, Kaplan Buys Quest, a Chain of Commercial Colleges, Chron. Higher Educ., June 28, 2000 (discussing Concord aspect of Kaplan's online education), available at http://chronicle.com/free/2000/ 06/2000062803n.htm.

99. See Johnson, supra note 21 (describing pressure to market effectively).

100. Of course, many bricks-and-mortar institutions would likely do the same.

101. See generally Blumenstyk, supra note 98 (noting Kaplan purchase of some accredited, non-J.D. colleges).

102. Cf. Franklin Pierce Law Center (offering downloadable information on patents, trademarks and copyrights for artists, craftspeople, small inventors and business owners), at http://www.ipmall.fplc.edu (last visited Feb. 18, 2001).

103. Cf. Infospace (offering non-legal example of syndicator offering content), at http://www.infospace.com/info/index.htm; Kinecta (same), at http:// www.kinecta.com; Adam (same), at http://www.adam.com; Medscape (same), at http://www.medscape.com.

104. Cf. Medibuy.com (offering example of medical supplies procurement), at https://www.medibuy.com. 
mats. ${ }^{105}$ Consolidators will find a market once some disaggregation has occurred within the offerings of traditional law schools. Assume, for example, that schools begin to offer some individual courses on a distance basis (i.e., you can buy torts or copyright law independent of the J.D.), it is likely that Internet-based consolidators will emerge that will offer J.D. degrees based on contributions from many different schools. This disaggregation likely will occur initially as schools try models such as DE collaborations with other schools or offer a sub-set of J.D. courses to, say, non-U.S. or LL.M. students. ${ }^{106}$

The other type of pure-play e-businesses that will swiftly emerge are new species of intermediaries (or infomediaries) that, initially at least, will insert themselves into the law school application process. This insertion will dramatically reduce the information cost asymmetries suffered by those applying to law school, perhaps even to the extent of enabling computer-mediated bidding wars by law schools for highly qualified applicants. Law schools, like many other providers of intermediate goods, practice price discrimination and do so through the vehicle of tuition scholarships, from a few hundred dollars to a "full ride." In the law school market, price discrimination is primarily based on the academic quality of the applicant, although some occurs with a view to increasing the diversity of the student body. ${ }^{107}$ Traditionally, however, schools have been tight-lipped about the amount of scholarship money and their criteria for extending it. ${ }^{108}$ While a few savvy applicants have learned to leverage offers from one school to another, generally the market has been opaque and the schools clearly have had control of the price discrimination game. Infomediaries will revolutionize this process as they match applicants,

105. Cf. Pro2net (offering comprehensive online resource for professions in accounting, financial services, human resources, insurance and law), at http:// legal.pro2net.com.

106. See Evans \& WURSTER, supra note 69 , at 39-67 (discussing general destruction theory).

107. In other industries, price discrimination may be based on customer convenience (e.g., an airline ticket purchased one week prior to the flight is generally more expensive than one purchased three weeks earlier). In other cases, it may be based on the supplier's marginal cost (e.g., an airline may dramatically discount its few remaining seats on a flight in the final 24 hours prior to the flight).

108. For an example of a typical law school financial announcement, visit the Boston University webpage which states:

WE ARE COMMITTED TO MAKING LEGAL EDUCATION affordable for BUSL students. Through scholarship awards, federal loans, and, for continuing students, through work-study awards, the School of Law provides funding for over 82 percent of enrolled J.D. students. Although we attempt to provide as many scholarships as possible, our funds are limited and thus, priority for need-based aid is given to students with the strongest academic records. (Admissions decisions are made without consideration of financial need).

Financing Your Education, Boston University School of Law, at http://www.bu. edu/law/finaid/ (last modified Jan. 19, 2001). 
schools and financial aid packages. ${ }^{109}$ Emerging with these infomediaries will be other $\mathrm{B} 2 \mathrm{C}$ models such as reverse auctions that will assuage the accuracy with which LSAT scores are matched with scholarship dollars. ${ }^{110}$ Together these e-commerce models will explode the heretofore-comfortable scenario, making the entire price discrimination system more transparent for applicants.

The decline of applicant information costs will also force bricks-andmortar law schools to re-evaluate their value propositions and re-think their marketing strategies and budgets. Law schools are providers of intermediate goods, a class of commerce that is essentially a means to an end. ${ }^{111}$ Generally students seek to attend law school because the J.D. degree qualifies them in whole or substantial part to practice law. The greatest commercial danger faced by providers of intermediate goods, particularly in thick markets, is commodification (and, thereafter, price pressures caused by increased competition). Law schools have avoided commodification by rigorously asserting their individuality and unique excellence (the basis for every decanal presentation to alumni!). Across the country, however, law schools are far more similar than they are different, and far more varied in quality than they would like to admit. Yet preInformation Age law school applicants have been denied information about the relative strengths and weaknesses of competing law schools. In part, law schools have achieved this by effectively controlling the ABA accreditation process, the LSAC admissions process, and having a trade association ("AALS") that promotes egalitarianism. In the absence of objective information flowing to applicants, schools have been able to differentiate themselves and so avoid commodification. In this information vacuum, schools have differentiated themselves by unchallenged self-promotion and positive word of mouth. This status quo benefits most law schools. Historically, national schools are not pressured much by competitors from below, while smaller, perhaps less well funded schools can continue to enjoy regional glory. It was this cozy world that U.S. News $\mathcal{E}$ World Report torpedoed. That infamous annual report and its fellow travelers ${ }^{112}$ have tended to make the law school market more transparent-a trend that will be magnified many times in the Information Age. As applicants benefit from lower information costs, schools will either find their claims

109. See, e.g., Embark, supra note 89 ,(creating online market exchange designed to facilitate interactions "among students, learning institutions and related product and service vendors"). com.

110. Cf. Priceline.com (providing online auctions), at http://www.priceline.

111. For example, airline passengers typically will fly to the East Coast because they want to get to New York rather than because they want to fly or experience a particular airline. Similarly, patients visit a doctor's office because they wish to be healed, not because of any intrinsic pleasure derived from filling out insurance forms or being treated.

112. Cf. Review.com (providing insight into what law school is like), at http:// www.review.com/law. 
of excellence challenged and will be exposed as frauds, will face commodification (and thus price pressure) or will be forced to invest in potentially expensive differentiating strategies.

Clearly, law schools will become far more aggressive marketers and begin to apply more sophisticated e-commerce models to their web site design and functionality. This path will be resisted at first; after all, our schools' private fascination with external "fashion parade" rankings is equaled only by our publicly voiced and institutional disdain. ${ }^{113}$ As the Internet creates a more transparent law school market, and DE begins to chip away at naturally protected geographical markets, the pressure to market aggressively will be overwhelming. ${ }^{114}$ Data will be teased from potential law school applicants who visit a law school site and rich, personalized multimedia information will be sent in response. ${ }^{115}$ As competition for highly qualified applicants increases, admissions professionals will be forced online onto their own sites to provide personal (not merely personalized) "live" chat-based customer service and rapid response to financial assistance questions. In a world of opinion sites ${ }^{116}$ updated in real time $\mathrm{u}^{117}$ and e-commerce comparison "bots" continually searching for tuition discounts, ${ }^{18}$ traditionally tolerated student or peer reviews of our teaching and U.S. News $\mathcal{E}^{2}$ World Report rankings ${ }^{119}$ will appear pedestrian, even trivial!

113. See generally Statement Regarding Law School Rankings, Ass'N AM. L. Schs. (making statement regarding law school rankings), at http://www.aals.org/ rank.html (last visited Feb. 18, 2001); Stephen P. Klein \& Laura Hamilton, The Validity of the U.S. News and World Report Ranking of ABA Law Schools, Feb. 18, 1998 (providing validity of study), at http://www.aals.org/validity.html:

114. Traditionally, law schools have enjoyed geographical monopolies both for input and outputs. These monopolies are the result of the high information costs suffered by applicants and hiring law firms as to, inter alia, the quality of geographically distant law schools. See Daria Roithmayr, Barriers to Entry: A Market Lock-in Model of Discrimination, 86 VA. L. Rev. 727, 790-93 (2000) (discussing law school monopoly benefiting from uniform market).

115. See Lisa Guernsey, A College Leads the Way in Requiring Online Applications, N.Y. Times, May 25, 2000, at D11 (discussing how West Virginia Wesleyan College will likely be first well-known, higher education institution to accept only online applications), available at http://www.nytimes.com/library/tech/00/05/circuits/ articles/25virg.html.

116. See, e.g., Teacherreviews.com (offering opinions of students on particular teachers), at http://www.teacherreviews.com.

117. See, e.g., Epinions.com (updating in real time) at http://www.epinions. com.

118. See, e.g., MySimon (functioning as online search-bot), at http://www. mysimon.com/index.html.

119. See, e.g., Top Law Schools, U.S. News \& WORLD REP. (ranking top 50 law schools), at http://www.usnews.com/usnews/edu/beyond/gradrank/law/ gdlaw.htm (last visited Feb. 18, 2001). 


\section{B. Fleshing Out the Click-and-Brick Model}

The click-and-brick model that will hold sway during the next decade will do so almost entirely because of the negatives inherent in other models; it will be somewhat palatable to law faculty, will be the least objectionable to external interested parties, such as accreditation bodies and potential employers, and will produce effective weapons with which to repel pure-play insurgents and (here a positive) exploit what I continue to believe are the very real social and professional benefits that come from real space interaction. What remains unclear is whether the model will be sustainable and whether, despite its short-term defensive advantages, it will be seen in later years as the camel's nose that brought disaster into the traditional law school tent.

In looking further "inside" the law school and the impact of technology and e-commerce principles on its core functions, it helps to attempt to disaggregate, even deconstruct the law school edifice. Key areas of the enterprise must be re-engineered in order to foster the click-and-brick model. I take four areas to serve as examples: the library, the law journal, teaching "content" and the teaching and learning space.

The good law school library is not just a place of storage, but one of highly professional research service. However, it is already severely marginalized by technology, and those hawking pure-play distance learning services will seek to marginalize it as an institution; librarians, professional information intermediaries, are simply the first established legal education professionals to be directly threatened by technological disintermediation.

The ubiquity of the Internet, particularly through wireless technology, gives libraries opportunities to both virtualize the information experience and make better use of the library for those users inside it. The technology also opens up some fascinating new possibilities. For example, since the network will "know" where the user is in the library and where all the books. are (via Global Positioning System-like technologies), ${ }^{120}$ how important will cataloging or shelving be? The research library should also get very smart: the network will comprehend your research interests from your profile, personalization, the book you are currently using and the article and cases you read earlier online, so it should be able to intelli-

120. See Kevin Washington, Locator System Draws Bead on Better Accuracy; GPS: The Federal Government Has Stopped Scrambling Signals, Rendering Devices Using the Navigation System Far More Precise, Bal. T. Sun, May 8, 2000, at 1C (discussing federal government making global positioning system ten times stronger than before). The U.S. military no longer scrambles GPS signals, which reduced the accuracy of civilian location systems. See id. Accuracy is now between forty-eight and sixty feet. See generally Ben Hammer, GPS to Do Wonders for Wireless Browsing, Indus. STANDARD, May 25, 2000 (discussing uses of GPS technology), at http://www.cnn.com/ $2000 / \mathrm{TECH} /$ computing $/ 05 / 25 / \mathrm{gps}$.and.wireless.idg/index.html. The user will be locatable via GPS chips embedded in mobile phones or other handhelds. See About SiRF (describing GPS technology), at http://www.sirf.com/about.htm (last visited Feb. 18, 2001). 
gently suggest the next step for your research. When library stacks have gaps in coverage (or someone else is using the book) the network can patch the omission by instantly transmitting the missing text to your handheld. However, the most interesting questions concern the library business model itself. Law libraries already use compact shelving, off-site storage, consortia-based purchasing policies and inter-library-loan-in other words, the storage (or product) and service (e.g., research advice) components of the library model have begun to disaggregate. This trend is likely to continue, and the future of the law library might well be one of regional (consortium or commercial-based) storage of hard copy, but local, school-based provision of research services. The best law libraries have already moved beyond the storage stereotype to research professionalism; ${ }^{121}$ their continuing challenge will be to reengineer themselves around their professionals' skill sets, rather than their local holdings ${ }^{122}$ and to reestablish their value proposition in an environment in which content no longer equates to defined physical spaces.

Close to the heart of most U.S. law schools is the law review publication. Law reviews provide a training ground for many of our students, assist the functioning of law school tenure and promotion committees, and save our law libraries from the massive costs associated with peer-reviewed, commercially published journals such as those in the natural sciences. However, in a click-and-brick world these assets may not be sufficient to guarantee the law review's survival. ${ }^{123}$ Quintessentially linear, law review articles also are far too long. Typically they contain much that is repetitive of sources and analysis rather than novel constructs. ${ }^{124}$ They

121. See Richard A. Danner, Redefining a Profession, 90 L. LiBr. J. 315, 345 (1998) (noting changing role of librarians). Danner goes on to state the following:

[T] he librarian's professional grounding in content expertise will remain important, but in a new sense. There is now and will be a growing need for professionals who can sift and sort through information, not only to locate pieces of information, but to put those pieces into context, to weigh and compare different items, identify, authenticate, and validate them. As put by Paul Saffo: "in a world of hyper abundant content, point of view will become the scarcest of resources." Librarians and technologists alike should be thinking more about context and point of view than about content and access as separate concepts. The ability to provide context to the client's process of information seeking will be key to the future of the information professions, but context is a product of both content and access and can be provided only through consideration and Id. understanding of both elements.

122. Cf. Chris Maiden, From Law Librarian to Digital Alchemist-Continuity and Persistence in a Noble and Learned Profession, 30 L. LIBR. 215, 215 (1999) (noting changing role of librarians).

123. See generally Bernard J. Hibbitts, Last Writes? Reassessing the Law Review in the Age of Cyberspace, 71 N.Y.U. L. REv. 615, 616 (1996) (analyzing traditional law reviews from "perspective of present age cyberspace"). journal.

124. Needless to say, none of these criticisms apply to this article or law 
also take too long to publish (and thus far the obvious web solution to this has not had a major impact). In contrast, the better scientific journals are well suited to transfer to the web; articles are shorter, ${ }^{125}$ more intelligently indexed and cross-linked and are designed with collaboration in mind. ${ }^{126}$ This distinction between our culture's traditional publications and those from other disciplines will be further magnified as content is increasingly retrieved using handheld devices and other appliances with smaller screens. ${ }^{127}$ The Internet-based researcher is primarily interested in current awareness ${ }^{128}$ and thoughtful analysis and commentary. For now, we approximate these needs with commercial tools ${ }^{129}$ and the few excellent, closed lists that have thoughtful and frequent contributions. ${ }^{130}$ In the Information Age the dinosaur law reviews may continue to serve the needs of the careers of student editors and faculty but will become increasingly marginalized as research resources. ${ }^{131}$

The teaching content (the next generation casebook) for the clickand-brick has not yet appeared. Of course, readability and other issues have dulled development, though new displays ${ }^{132}$ font ${ }^{133}$ and appliance $^{134}$ technologies will cure those problems. ${ }^{135}$ It is notable, however, that pure electronic texts seem to be establishing themselves in other disci-

125. See, e.g., Med. Ethics Newst., Lahey Clinic (providing example of web site with shorter articles), at http://www.lahey.org/Ethics/Newsletter/ newsletter.stm.

126. See, e.g., BMJ Publishing Group (providing example of web site designed with collaboration in mind), at http://www.bmj.com.

127. For a further discussion of the distinction between traditional and nontraditional publications, see supra notes $63-65$ and accompanying text.

128. The Internet excels in providing current awareness tools and in pulling data from diverse sources for comparison and other manipulation. It also supplies completeness, all the data that's available, coupled with the tools needed to weave together relatively small pieces of data to be more meaningful. See, e.g., CNN Headline News (providing current events news and links to related cites for more analysis), at http://www.cnn.com.

129. . See, e.g., Bureau of National Affairs, Inc. (providing example of product catalog), at http://www.bna.com/prodcatalog/index.html.

130. See, e.g., Learning Cyberlaw in Cyberspace (providing example of closed list that has frequent contributions), at http://www.cyberspacelaw.org/index.html.

131. For a discussion of a somewhat different take on possible disaggregation issues related to scholarly publishing, see Marin Roger Scordato, The Dualist Model of Legal Teaching and Scholarship, 40 AM. U. L. REv. 367, 371-83 (1990).

132. See, e.g., E-INK (providing example of web site discussing new display technology), at http://www.electronic-ink.com/index.htm.

133. See, e.g., Update on ClearType Font Technology and LCD Displays, Apr. 7, 1999 (providing example of new font technology), at http://www.microsoft.com/ hwdev/video/clrtype.htm.

134. See, e.g., eBook (providing example of new appliance technology), at http://www.rocket-ebook.com.

135. See Doreen Carvajal, 4 Giants Set to Embrace Electronic Publishing, N.Y. Times, May 23, 2000, at $\mathrm{Cl}$ (noting that, in age of digital rush, three publishing agencies and Microsoft plunge into electronic literary market), available at http:// www.nytimes.com/ library/tech/00/05/biztech/articles/23books.html. 
plines first. ${ }^{136}$ The legal market still does not provide incentives to author electronic texts, partly because we lack any tradition of using multimedia or other non-textual content in our teaching. Delivery platform aside, probably the key piece of missing content that needs ramping up for both distributive and distance learning models alike are interactive quizzes and similar self-evaluating products that provide quantitative and qualitative indications of progress through a course. ${ }^{137}$ Finally, while traditional publishers, the law teacher, his or her school and the institution's distance partners will be the primary suppliers of content in the click-and-brick world, it would be a mistake to think they will be the exclusive providers. Ubiquity and the next generation of messaging potentially will connect every student or, say, every torts student (or torts student using the same casebook) wherever they are in the world. Imagine a room (real or virtual) of students with simultaneous access to every other student's notes, outlines or professorial hypotheticals all being updated in real time.

What will be the technical characteristics and functions of the clickand-brick classroom or, more accurately, the teaching and learning space? ${ }^{138}$ Somewhat ironically, given the forces driving technology into legal education, the online classroom (or classroom supplement) of the next decade will be technologically quite conservative, with much of the emphasis (and investment) channeled towards the pedagogy, content-development (particularly in the area of interactive, self-learning modules) and seamless, trouble-free delivery. The hybrid law school space will use relatively little video, primarily because of cost and bandwidth. Instead, we will see video used as short clips, used for contextualizing stories or fact patterns. Some streamed video talking heads will be used to alleviate the tedium of PowerPoint or web text. ${ }^{139}$ We will see almost universal adoption of web forum and e-mail applications deeply embedded in our school intranets. There will also be considerable use of conferencing technologies (with or without web cam-quality video and virtual whiteboards) for teaching, virtual office hours and, in the library and career services offices, virtual help desks.

Ubiquity will further increase S2S and F2S communication and potential collaboration. Ubiquity generally makes for easier access to distributive and distance tools. Legal educators and their students generally do

136. See Lisa Guernsey, Bookbag of the Future; Dental Schools Stuff 4 Years' Worth of Manuals and Books into 1 DVD, N.Y. TimEs, Mar. 2, 2000, at G1 (noting establishment of electronic textbook in dental school), available at http:// www.nytimes.com/library/tech/00/03/circuits/articles/02dent.html.

137. See, e.g., CALI, (providing example of self-evaluating, law-related web site), at supra note 11.

138. See generally Johnson, supra note 21 (recognizing that new computer age will have drastic effect on traditional law school environment).

139. See, e.g., RealNetworks (providing example of medium bandwidth tools, such as RealPresenter, that will alleviate tedium of PowerPoint or webtext), at http://www.realnetworks.com/products/presenter/info.html; Macromedia (same), at http://www.macromedia.com. 
not perform fieldwork or move continually from one space to another as a matter of necessity, so handhelds and appliances are probably less important than for, say, natural scientists or even practicing lawyers or clinicians. However, faculty and student appliances will acquire research power almost beyond comprehension. The Internet is peerless when it comes to creating new social groups or bonding together established communities; thus, most law schools will build intranets (that themselves will be expanded to extranets so as to include alumni and employers) on top of their internal networks, thus fostering nascent community models.

However, re-engineering the law school classroom will not only be about the increased use of technology. Pure-play DE providers will have a compelling value proposition not only because of the economics of their broadcast model, but because they are not using teaching revenue to subsidize other activities such as faculty research. For the click-and-brick law school to have a competitive value proposition, we will likely have to redistribute resources from research and service back into teaching (although this is not without its dangers as it threatens the "academic and scholarly" value proposition that will be central to the click-and-brick's message).

The click-and-brick law school must support not only its traditional resident student, but also two new types of distance student. First, schools will seek to accommodate LLM students and part-time JD students who wish to participate in an agreed percentage of classes from remote desktops. Second, classrooms will be open to students at schools that are part of DE consortia formed to share resources and specialties across campuses. For the click-and-brick model to be sustained, the law school technologies must be used to increase the value not only of the computermediated interactions, but also to increase the value of the live classroom events. Yet, therein lie some paradoxes and questions. For example, how successfully will we be able to integrate our DE and non-DE populations (an extreme version of a question faced by law schools that have both regular and part-time or evening divisions)? In e-commerce the bane of the click-and-brick has been management reluctance to allow the 'net part of the enterprise free reign because of concerns that the institution's bricks-and-mortar market will be cannibalized. Will click-and-brick law schools be prepared to let the "pure-play" elements of the hybrid institution have free reign?

An e-commerce verity is that a "pure-play" has inherent advantages compared to a click-and-brick hybrid in part and, as already discussed, because of the reluctance of the hybrid to allow the "click" aspects of the model to cannibalize the "bricks" aspects. However, there is much about the bricks-and-mortar law school that could be exploited in a hybrid. ${ }^{140} \mathrm{~A}$

140. Cf. Robert D. Hof, Clicks Don't Need Mortar, Bus. Wk. E-Biz, June 5, 2000, at 126 ("[S]omebody eventually will come up with a compelling bricks-and-clicks combo that adds up to more than the sum of the parts .... [F] ew retailers are even close to demonstrating to customers what the benefits might be. By the time they do, they may find e-tailers are already there."). 
successful click-and-brick institution requires vibrant real and virtual spaces. It must offer more small classes and skills courses, maximizing the opportunity for high value (albeit high cost) interaction. For the clickand-brick hybrid to flourish it must not ignore the bricks; we must continually upgrade the quality of our real space. Indeed, as more and more teaching and research moves to the Internet, some of our classroom and library space must be converted to useful (albeit 'net-connected') social space. The click-and-brick school will be selling itself (and, compared to a pure-play, at a premium) as a place of community and interaction, of indepth analysis and lifetime friendship-we must reassess our spaces, from lounges to libraries to cappuccino bars with that in mind. Each law school must also revisit its mission and its marketing message. In a national or global "connected" market it is going to be increasingly difficult to be a "local" law school, although no doubt some schools will seek to foster some "local" or land grant ${ }^{141}$ image as their distinction. More likely, however, law schools will continue to try to distinguish themselves with specialty areas or centers of excellence.

For the click-and-brick to succeed we have to swiftly resolve some of the impediments to $\mathrm{DE}$ that in less pressing times could have been left to fester and percolate in time-honored legal education fashion. We must provide incentives to our faculty to create the next generation of online content and teaching tools. We need to agree on how to make distancelearning credits portable among our partner (consortia) schools. We must also address the potential faculty versus school issues such as the ownership of classes ${ }^{142}$ and presentations, ${ }^{143}$ and navigate issues such as residuals and non-compete clauses. ${ }^{144}$ We must work to remove these im-

141. See, e.g., Act of July 2, 7 U.S.C. $\$ 301-308$ (1862) (granting land to colleges).

142. See, e.g., Academic Policy and Planning Committee Distance Education Policy, San Diego State University, Apr. 6, 2000, Implementation Principles I 1d-f, Apr. 6, 2000 (addressing ownership rights and faculty compensation related to distance learning), at http://www.rohan.sdsu.edu/dept/senate/sendoc/distanceed. apr2000.html.

143. See, e.g., Hays v. Sony Corp. of Am., 847 F.2d 412, 41417 (7th Cir. 1988) (providing example of case where ownership of presentation was at issue); Weinstein v. Univ. of Ill., 811 F.2d 1091, 1093-98 (7th Cir. 1987) (same). See generally Todd A. Borow, Copyright Ownership of Scholarly Works Created by University Faculty and Posted on School-Provided Web Pages, 7 U. Miami Bus. L. Rev. 149 (1998) (noting debate over ownership between faculty and school officials); Georgia Holmes \& Daniel A. Levin, Who Owns Course Materials Prepared by a Teacher or Professor? The Application of Copyright Law to Teaching Materials in the Internet Age, 2000 BYU EDUC. \& L.J. 165 (2000) (same). An additional issue involves the ownership of class notes as between faculty and student. See generally Williams v. Weisser, 273 Cal. App. 2d 726 (Cal. Dist. Ct. App. 1969) (discussing proper ownership over class notes).

144. See, e.g., Jeffrey R. Young, Harrard Considers Limits on Teaching Online Courses for Other Institutions, CHRON. Higher Educ., Apr. 25, 2000 (discussing noncompete clauses with respect to online courses), available at http://chronicle.com/ free/2000/04/2000042501u.htm. See generally Developing a Distance Education Policy for 21st Century Learning, AM. Council on Educ., Mar. 2000 (noting importance of non-compete clauses), available at http://www.acenet.edu/ 
pediments even in the face of objections that, in the process, we will be making it easier for our pure-play competitors to establish credibility and even demand accreditation. ${ }^{145}$

To play in the hybrid world you must have table stakes and, in this context, the stakes are sound strategy, teaching content, good technology, and well-trained professors and IT support. In a world of DE mere consumers will not survive; only content and technology providers will find partners and networks and will continue to attract top students and faculty. Finally, and as I detail in the sections that follow, we must retune our endeavors to be more responsive to the realities of the effects of technology on legal practice and substantive law.

\section{Future Law and Practice-Curricular Planning for THE INFORMATION AGE}

Given the entrenched position of many in legal education, any suggestion that the law school curriculum should be forward-looking may be novel. However, just as the structure, processes and pedagogies of the click-and-brick law school must be reassessed and then reengineered, so we must revisit the value proposition offered by our curriculum. Many of the curricular suggestions that follow are based on the technological changes that surround us. Therefore, a fair question might well be, why can't the curriculum gradually absorb these changes as it has done others in the past? The answer is that, unlike other social or economic phenomenon that legal education previously has adapted to, technological development moves too quickly for a reactive model. The technology refresh cycle is fast, nimble, exponential and seems sustainable. As a result, the curriculum needs major remodeling just to keep it in sight. The successful click-and-brick law school will be one that continually updates its curriculum, driven by relevance and responsiveness, not by fad.

One place to start the analysis of the curriculum of the near future is Andy Grove's comment that "there will be no such thing as Internet business-because all businesses will be using the Internet in their operations." 146 The question is whether it will be the case that, in a related time frame, there will be no such thing as Internet or Cyberspace Law-because all law will be Internet law?

The short answer is "no." I am not suggesting that the entire curriculum should be dumped. Many of the technology-related legal issues that we have faced over the past decade have been caused by over-hasty reactive

washington/distance_ed/2000/03march/distance_ed.html; Distance Education and Intellectual Property Issues, American Association of University Professors (discussing new technological school environment), at http://www.aaup.org/distnced.htm.

145. For a further discussion of removing these impediments, see supra text accompanying note 28.

146. Andy Grove, The Confederation of the British Industry, INTERNET TrMEs, Sept. 15, 1999, at http://www.glreach.com/eng/ed/it.php3. 
legislation ${ }^{147}$ or older statutory language that did not contemplate the Information Age; ${ }^{148}$ such difficulties likely will decrease as the statutes themselves go through refresh cycles. Similarly, there are signs that some "first decade" legal firestorms, such as those swirling around questions of jurisdiction, ${ }^{149}$ are now under control. Equally, it may be that substantive areas that have very strong normative underpinnings and relatively openstructured doctrine will be better at absorbing new, Internet-oriented fact patterns and challenging issues. For example, tort law can probably handle the new jargon of cybertorts, ${ }^{150}$ such as cybersmearing ${ }^{151}$ or cybermalpractice, ${ }^{152}$ and develop its doctrine to meet emerging fact-patterns involving Internet fraud, hate e-mail and the liability exposure of infomediaries.

It would also be a mistake to suggest that Internet or computer technology has an exclusive call on curricular reform. Technologies of all sorts have fueled the economic growth of the first decade of the Information Age and the results of all this economic growth will have to be factored into planning legal services and hence legal education. For example, e-commerce-fueled prosperity will increase trust and tax work and stimulate real estate and other areas that feed leisure industries. Further, we should assume that the health/biotechnology field will continue to grow exponentially and with it the number of credit hours allotted. The mapping of the human genome is close to completion, ${ }^{153}$ "designer"

147. See, e.g., Reno v. ACLU, 521 U.S. 844, 849 (1997) (striking down most provisions of Communications Decency Act).

148. See, e.g., United States v. Kammersell, 7 F. Supp. 2d 1196, 1198 (C.D. Utah 1998) (defining interstate crime); Nicolas P. Terry, Legal Pitfalls of Cybermedicine, in Med. ETHICs 4, Lahey Clinic (Winter 2000) (describing problems with providing medical services over internet), available at http://www.lahey.org/ PDF/Ethics/Winter_2000.pdf.

149. See Panavision Int'l, L.P. v. Toeppen, 141 F.3d 1316, 1319-21 (9th Cir. 1998) (providing example of case where jurisdiction was at issue); Barrett v. Catacombs Press, 44 F. Supp. 2d 717, 722-31 (E.D. Pa. 1999) (same); CIVIX-DDI v. Microsoft Corp., 52 U.S.P.Q.2d 1501, 1504-08 (D. Colo. 1999) (same); GTE New Media Servs. v. Ameritech Corp., 21 F. Supp. 2d 27, 36-44 (D.D.C. 1998) (same).

150. See, e.g., Ebay v. Bidder's Edge, Inc., 100 F. Supp. 2d 1058, 1069-71 (N.D. Cal. 2000) (noting adoption of traditional tort theories in cyberspace fact patterns).

151. See, e.g., Phyllis Plitch, Defense Sought for Anonymous Online Posters, Wall ST. J., Feb. 22, 2000, at B9C (discussing recent trend of "cybersmearing").

152. See, e.g., Nicolas P. Terry, Cyber-Malpractice: Legal Exposure for Cybermedicine, 25 AM. J.L. \& MED. 327, 336-66 (1999) (discussing cyber-malpractice litigation).

153. See generally Human Genome Project, U.S. Department of Energy (noting that goals of project are to identify all genes and sequences in human DNA), at http://www.ornl.gov/hgmis (last modified Feb. 14, 2001); Researchers Report Completing First Step in Mapping Human Genes, CNN INTERACTrve, Apr. 6, 2000 (announcing identification of chemical makeup of human genes), available at http:// www.cnn.com/2000/HEALTH/04/06/genome.mapping/index.html. 
life ${ }^{154}$ and death issues will proliferate and artificial intelligence will continue its relentless pursuit of the simulation of human thought. ${ }^{155}$

If an invigorated curriculum, one that is both relevant to and captures the dynamic quality of the law and its practice, is key to the successful click-and-brick, what are the major changes that will be wrought by Internet or computer technology, and where should the curriculum reformer begin? Again, it helps to ground the inquiry with our sense of ubiquity and our themes of globalization and convergence. With these operators in mind, what follows below is a discussion of five areas, themes or issues identified as most clearly impacting and requiring redesign of substantive legal and legal educational space: 1) the likely transformation of substantial practice areas into pure-play e-services; 2) the need to nurture the new global market; 3 ) management of a potentially serious lawtechnology disconnect; 4) radical changes in transactional law (primarily because of the impact of disintermediation); ${ }^{156}$ and 5) the likely emergence of an entire new area of law that I will label "cyberspace access law." 157

\section{A. Legal Practice: Turmoil and E-commerce}

Notwithstanding its rich history, traditions and ethics, the practice of law is a service. As has been noted, " $[t]$ he Industrial Boom was built on the mass production of goods. The Internet Boom is built on the mass production of services." 158 The question is whether, as the web is transformed from linked content to a network of interconnected services, legal practice can adapt to e-commerce models. For law school space, the answer will impact not only the curriculum, but also will help determine the vitality of our future inputs and outputs.

154. See, e.g., Diana Cammack, Arthur C. Clarke's Visions of the Future, GloBAL SituATION REPORT, Mar. 10, 1999 (predicting that first publicly admitted human clone will be announced in 2004), at http://www.gsreport.com/articles/ art000072.html; Gene Targeting, PPL-Therapeutics (announcing successful cloning of pigs), at http://www.ppl-therapeutics.com/Welcome/Gene_Targeting/ gene_targeting.html; Scientists Produce Five Pig Clones, BBC News, Mar. 14, 2000 (announcing cloning of pigs by PPL-Therapeutics), at http://news.bbc.co.uk/hi/english/sci/tech/newsid_676000/676906.stm.

155. See generally The Artificial Intelligence Laboratory at M.I.T., Massachusetts Institute of Technology (attempting to understand human intelligence at all levels, including reasoning, perception, language, development, learning and social levels, and to build useful artifacts based on intelligence), at http:// www.ai.mit.edu.

156. For a discussion of radical changes in transactional law, see supra text accompanying note 53 .

157. For a discussion of the emergence of cyberspace access law, see supra text accompanying note 56 .

158. Antoin O'Lachtnain, Scale Scale Scale, NUA Making It Work, NUA, Sept. 17, 1999 (attempting to make sense of how technology can be implemented to make one's organization, community or society work better), available at http:// www.nua.ie/making_it_work/archives/issuel no32.html. 
To an extent, the ability of a law firm to make the successful transformation to e-service provision will be a function of the other issues currently faced by the profession. The traditional law firm structure is under fire from several directions. First and obviously, a continual period of acquisition and merger will lead to the domination of the profession by very large national firms. Second, resolution of the debate on multidisciplinary practice ("MDP") ${ }^{159}$ almost inevitably will be resolved in a way that leads to even larger groupings or hybrid entities. ${ }^{160}$ There is frequently a correlation between size and technology implementation. ${ }^{161}$ Not surprisingly, the large accounting firms have been aggressive IT adopters. ${ }^{162}$ One way or another, the industrialized law firm is around the corner and it will be very different from the "traditional" firm. As size increases, so will the use of para-professionals and outsourcing. Within a decade, the quality of work and its ability to satisfy the law graduate likely will decline.

Thus far, the law and technology debates surrounding the practice of law have concerned themselves with the choice and efficiency of technolo-

159. See generally Law Practice Management Section, ABA (providing "a crib sheet of information for lawyers and non-lawyers on how they can work together to serve the needs of a common client, and challenges associated therewith), at http://www.abanet.org/lpm/ mdp/mdphome.html. See generally Giancula Morello, Note, Big Six Accounting Firms Shop Worldwide for Law Firms: Why Multi-Discipline Practices Should Be Permitted in the United States, 21 Fordham INT'L L.J. 190 (1997) (explaining why multi-disciplinary practices are becoming more appealing).

160. See New York State Bar Ássociation, State Bar Committee Report Would Permit Lawyer/Non Lawyer "Side by Side" Business Arrangements, May 2, 2000 (noting NYSBA's special committee that recommended some forms of multidisciplinary practice, but recommended against partnerships with non-lawyers and multidisciplinary practice in which non-lawyers have any degree of ownership or control over practice of law), at http://www.nysba.org/media/newsreleases/2000/ mdp.html; Philadelphia Bar Association, Philadelphia Bar Association Multidisciplinary Practice Task Force Report and Recommendation, Mar. 10, 2000 (noting that, on March 23, 2000, Philadelphia Bar Association became first such association to permit MDPs, albeit those at least $51 \%$ lawyer-owned), at http:// www.philadelphiabar.org/about/news/newspage; see also Colorado Bar Association MDP Task Force, Colorado Bar Association, May 2000 (providing another example of state bar association raising MDP awareness), at http://www.cobar.org/ mdp/ reporttoc.htm. See generally Margaret A. Jacobs, Accounting Firms Covet Forbidden Fruit: Piece of the U.S. Legal Market, WALL ST. J., May 31, 2000, at B1 (discussing how preventing large accounting firms from owning U.S. legal firms "shields lawyers from healthy competition").

161. For a discussion denying the frequency of this correlation, see infra note 172 and accompanying text.

162. See, e.g., KPMG Consulting \& Cisco, Cisco Publishing (noting Cisco investment in KPMG), at http://www.cisco.com/warp/public/756/partnership/ kpmg. MDP's are also very well-financed competitors in the legal market, attracting venture capital, investments from technology companies and cash from the consulting arms they are divesting. See, e.g., Price Waterhouse Coopers (implementing practices to attract and address concerns of venture capital groups), at http://www.pwcrc.com. 
gies chosen to improve the delivery of traditional legal services. ${ }^{163}$ The more intriguing question, however, concerns the extent that the practice of law itself can be converted into an e-service. ${ }^{164}$ At the retail or businessto-consumer end of the market, some "legal" services will simply disappear and be replaced by robust, scaled versions of existing retail software legal products. ${ }^{165}$ At the next level of complexity, we will see the arrival of vertical portals that will seek to do for law what DrKoop ${ }^{166}$ and WebMD ${ }^{167}$ have done for medical services by integrating customer-facing services and information, thus delivering customers into various product and service channels. ${ }^{168}$ The initial wave of legal services likely will be ticket clinics, wills and Chapter 13's, followed by basic real estate, commercial and family law ${ }^{169}$ matters. ${ }^{170}$ Low-cost providers likely will aggregate and create one or more H\&R Block-type models. ${ }^{171}$ Small retail bricks-and-mortar

163. See, e.g., Joy M. White, Tech Tools@ Work: How Lawyers Are Using a Few of Their Favorite Things, Law Practice Management: Special Technology Issue, ABA L. Prac. Today, Nov./Dec. 1999 (noting ways in which technology is changing legal practice), available at http://4.21.247.201/mag4_front.shtml.

164. See, e.g., AmeriCounsel (providing example of web site that provides legal services), at http://www.americounsel.com.

165. See, e.g., Nolo.Com (providing example of web site where users can obtain legal software), at http://www.nolo.com; Parsons Technology, Inc. (providing example of web site selling "Quicken Family Lawyer 99," software offering 100 legal documents that users can personalize), at http://www.parsonstech.com/ software/famlaw.html. See generally Unauthorized Practice of Law Comm. v. Parsons Technology Inc., 1999 U.S. Dist. LEXIS 813 (N.D. Tex. 1999), vacated, 179 F.3d 956 (5th Cir. 1999).

166. See Dr.Koop.com (providing example of web site that offers medical services and information), at http://www.drkoop.com.

167. See WebMD (providing example of web site that offers medical services and information), at http://www.webmd.com.

168. See Desktop Lawyer (providing example of web site that supplies legal services and delivers users to other service channels), at http:// www.desktoplawyer.net; see also AmeriCounsel, supra note 164 (revealing "flat fee menu" for legal services); Darryl Van Duch, Technology from Hell Challenges Lawyers, Scares ABA, AM. LAw. MediA, Apr. 5, 2000 (discussing fears associated with rapid growth of technology in legal industry), at http://www.lawnewsnetwork.com/stories/A20553-2000Apr4.html.

169. See, e.g., Divorcestore.com (providing example of web site where users can get domestic relations legal advice), at http://www.divorcestore.com.

170. See Terry Carter, Checkbook Credibility, A.B.A. J., June 2000, at 50 (discussing venture capitalists' role in dot.com businesses).

Venture capitalists are pouring an estimated $\$ 100$ million into dot.com web sites geared to the legal profession and especially to bringing lawyers and clients together. The sites are sprouting like mushrooms and they portend a revolution in the provision of legal services, and even in the way law is practiced, something the technology itself seems destined to do.

Id.

171. See, e.g., H\&R Block (providing example of web site where users can get tax, mortgage and investment services), at http://www.hrblock.com. 
law firms are likely to disappear from real space, except in the rare case where the firm can articulate some distinctiveness or value-add. ${ }^{172}$

Large and very large law firms will be under continual pressure to grow and thereby extract costs through scale. They will have to be resolutely innovative to be competitive with their accountancy-based rivals. They will also have to learn to move as fast as their cyberspace-dwelling clients. ${ }^{173}$ Legal work will be supplemented and complemented by the creation of legal software, client extranets and compliance training systems, which will force law firms into new and highly competitive markets. ${ }^{174}$ The cyberspace relationship between the large law firms and their corporate business will tend to follow more of a business-to-business model. As with the classic B2B model, even high-level corporate work will be put up for online bidding, ${ }^{175}$ while in large law firms the lawyer-client relationship will be almost totally defined by authentication to the relevant extranet.

The fundamental changes that will be coming to the practice of law and the structure of law firms must be tackled by our curriculum. The Professional Responsibility course will need improvement, and schools must examine the continued vitality of "retail law" course coverage, whenever the practice areas involved become essentially automated.

\section{B. Nurturing the Global Market}

Legal educators have long preached about the globalization of legal studies, yet infrequently have delivered a curriculum to match. ${ }^{176}$ With

172. There is a longstanding article of faith among legal technologists that the small firm can compete with the very large firm by aggressively pursuing technological solutions. I have grown skeptical of this argument primarily because of the high information costs suffered by the small firm and the very high capital costs of performing such a metamorphosis. These are the types of costs that can only be borne by large firms. See generally Sandy Ramlet, Toppling the Giant: Can Solo Lawyers Use Technology to Compete with Larger Firms and Win?, 26 A.B.A. L. PRAC. MAN. 34 (interviewing several small firms about effects of technology in competing with big firms).

173. See generally Matt Richtel, Old-Line Law Firm Links Up to the New Economy, N.Y. Times, Mar. 20, 2000 (noting that Washington D.C. law firm represents dotcom company and is making e-commerce its new focus), available at http:// www.nytimes.com/library/tech/00/03/biztech/articles/20data.html.

174. See, e.g., The Legal Knowledge Company (providing example of web site that is provider of legal compliance and education products and services, including Lucent Law School), at http://www.lrn.com/lrnsite/home3.html.

175. See Ralph Blumenthal, Lawyer Auction in an Auction Suit, N.Y. TIMEs, Apr. 22, 2000, at B9 (providing example of auction of legal work), available at http:// www.nytimes.com/library/arts/042200auction-lawsuit.html.

176. Compare New York University School of Law: The Global Law School (discussing NYU's Global Law Program), at http://www.law.nyu.edu/globallawschool/, with Harvard University School of Law Catalogue (discussing curriculum on International Legal Studies), at http://harvard.edu/students/catalog/icls.php. 
the Internet now delivering a global culture ${ }^{177}$ and marketplace and our technology putting real time language translation on our web appliances, ${ }^{178}$ how will substantive law and legal education contribute? With globalization, the fulcrum of the web will shift, and some erosion of the United States-centricity of the Internet is inevitable. This likely will result not only in some cultural backlash, ${ }^{179}$ but complex extraterritoriality issues addressed by content regulation ${ }^{180}$ and dispute resolution.

As far as potential legal clashes, the most likely antagonists are the United States and European Union ("EU"). For some time, the protection of the privacy for consumers' information was recognized as the first flashpoint that could lead to a trade war. ${ }^{181}$ A softening of the U.S. position, however, led to an accommodation. ${ }^{182}$ Nevertheless, other issues will rush to fill that vacuum, such as the possibility of the EU introducing its

177. See Pierre Lévy, French Professor Says Internet Will Create 'Collective Consciousness', Chron. Higher Educ., July 23, 1999, at A35 ("[N]ot only are all human colonies on the planet in contact, but they are forming one colony ... . [T] he nervous system of this colony is cyberspace.").

178. See generally Babylon Language Translator (discussing translator's ability to translate ninety percent of all spoken language), available at http:// www.babylon.com.

179. As Coca-Cola did before them, Amazon.com, AOL and Yahoo have led the reverse colonization of the old world. See generally Amazon.com, at http:// www.amazon.de; AOL, at http://www.aol.com/info/international.html; Yahoo, at http://chinese.yahoo.com.

180. See, e.g., People v. Felix Somm (May 28, 1998) (German case), at http:// www.cyber-rights.org/isps/somm-dec.htm; see also Joshua Kaufman, The Mein Kampf Minefield, LeGAL Times, Sept. 7, 1999 (discussing extent of Internet content regulation in contemporary society), available at http://www.lawnewsnetwork. com/stories/A5181-1999Sep3.html.

181. Compare Directive 95/46/EC of the European Parliament and of the Council of 24 October 1995 on the Protection of Individuals with Regard to the Processing of Personal Data and on the Free Movement of Such Data, Community Legislation in Force (protecting against unwarranted access of personal data), at http://www.european.eu.int/eur-lex/en/lif/dat/ 1995/en_395L0046.html, with International Trade Administration Safe Harbor Principles, Nov. 4, 1998 (providing U.S. response), available at http://www.ita.doc.gov/td/ ecom/menu.htm.

182. See Robert O'Harrow, Jr., U.S., EU Agree on Privacy Standard, WaSH. Post, June 1, 2000, at E01 (discussing approval by European leaders of pact enabling U.S. companies to collect personal information about European citizens while complying with strict EU privacy guidelines), available at http:// www.washingtonpost.com/wp-dyn/articles/A41418-2000Junl.html; see also Cover Letter from Ambassador David L. Aaron to U.S. Organizations Requesting Comments on the Newly-Posted Draft Documents, Mar. 17, 2000, available at http:// www.ita.doc.gov/td/ecom/aaron317letter.htm; Draft Safe Harbor Principles, Mar. 17, 2000, available at http://www.ita.doc.gov/td/ecom/Redlined Principles31600.htm; Keith Perine, EC Will Stand By 'Safe Harbor' Deal, Standard, July 27, 2000 (stating that European Commission will move forward with U.S. data-privacy agreement although European Parliament argued it was too weak), available at http://www.thestandard.com/ article/display/0,1151,17197,00.html. See generally Keith Perine, How Private Is Private Enough?, STANDard, Feb. 28, 2000 (criticizing U.S. data- privacy agreement and privacy guidelines), available at http:// www.thestandard.com/ article/display/0,1151,12348,00.html. 
own top-level domain, ${ }^{183}$ signaling a different approach to governance and the domain name-trademark interface from that applied in the United States and its satellites. ${ }^{184}$ Equally, the friction-free quality of the global market could be threatened by radically disparate or otherwise unfriendly taxation policies in the major trading groups. ${ }^{185}$

The other major threat to the global market made possible by the Internet is the re-Balkanization of the market by commercial players. Even within U.S. borders, those unable or unwilling to compete in a larger market will seek to erect trade barriers. For example, the disintermediated frequently will look to joint action in order to pressurize the upstream provider or to state legislative bodies to maintain their regional or local intermediary status. ${ }^{186}$ Thus, national and transnational antitrust law must police illegal horizontal agreements or vertical restrictive agreements that seek to resist the move to open competition. ${ }^{187} \mathrm{Fi}$ nally, antitrust analysis will be at a premium as intense merger activity together with worldwide partnerships and cross-marketing arrangements

183. See generally Dugie Standeford, European Nations Seek Top Level Domain Name for European Union, INTEll. Prop. L. WkLY., Feb. 15, 2000 (discussing European Commission's proposal to create top-level domain name, "TLD," for EU), available at http://www.lawnewsnetwork.com/practice/techlaw/news/A161332000Feb14.html.

184. See generally National Telecommunications and Information Administration (discussing role in managing IP address space allocation and obligating Internet Corporation for Assigned Names and Numbers ("ICANN") to manage such concerns), at http://www.ntia.doc.gov/ntiahome/domainname/agreements/ summary-factsheet.htm (last visited Feb. 18, 2001).

185. See, e.g., Edmund L. Andrews, Europe Plans to Collect Tax on Some Internet Transactions, N.Y. Times, Mar. 2, 2000, at A6 (discussing potential effects of taxation policies on global markets), available at http://www.nytimes.com/library/ tech/00/03/biztech/articles/02tax.html; see also European Parliament, Presidency Conclusions (Mar. 23-24, 2000) (discussing necessary transition into competitive economy by utilizing internet sources), at http://www.europarl.eu.int/summits/ lis1_en.htm; \#597PC0628: Proposal for a European Parliament and Council Directive on the Harmonization of Certain Aspects of Copyright and Related Rights in the Information Society, (document delivered on June 28, 1999) (discussing amended proposal for European Parliament and Council Directive on harmonization of certain aspects of copyrights and related rights in Information Society), available at http://europa.eu.int/eur-lex/en/com/dat/1999/en_599PC0250.html.

186. See Warren Brown, Internet Putting Car Buyers in Driver's Seat, WaSH. Post, Feb. 28, 2000, at A01 (discussing citizen's purchase of automobile by way of Internet); see also Matt Richtel, Internet Strains the Ties of Record Companies and Stores, N.Y. Times, Feb. 29, 2000, at C8 (discussing online record stores and cyberspace record industry), available at http://www.nytimes.com/library/tech/00/02/ biztech/articles/29music.html.

187. Equally, some heretofore-suspect vertical arrangements tying up intermediaries may well escape prohibition when suppliers can use technology to sell directly to consumers. Such a channel would arguably reduce the anticompetitive effects of those vertical arrangements. See generally Household Goods Forwarders Association, DOD to Address Vertical Integration Issues, PORTAL, May 11, 1997 (discussing effect of vertical integration capabilities in defense industry on competition), available at http://www.hhgfaa.org/portal/ may_97/may11.asp. 
convert company clusters, particularly Internet and media companies, into powerful keiretsu. ${ }^{188}$

\section{Avoiding a Law-Technology Disconnect}

Developmentally, law is challenged by technology and, even when inserted into a space, seems far too inefficient to be compatible with the needs of the Information Age. The former may be illustrated by looking at the state of intellectual property and privacy law where we are desperately searching for ways to push unpleasant genies back into their bottles, and the latter by questioning the relevance of law and its processes to modern e-commerce transactions.

During the first decade of the Information Age, the development of intellectual property law (particularly in its applicability to the emerging technologies) ${ }^{189}$ may be characterized as a series of missteps followed by draconian legislation. ${ }^{190}$ The domain name-trademark interface was fumbled and then followed by the passage of the Anticybersquatting Consumer Protection Act. ${ }^{191}$ An agreement could not be reached on the proposed Uniform Commercial Code Article 2B, leaving the widely criticized Uniform Computer Information Transactions Act in the hands of state legislatures. ${ }^{192}$ Meanwhile, the generally well-regarded Feist Publica-

188. See Stuart Lauchian \& Simon Goodley, 7 Days; Gearing Up for the Biggest Virtual Marketplace Yet, Computing, Mar. 9, 2000, at 22 (discussing joint B2B venture between General Motors, Ford and Daimler-Chrysler for car parts); see also $E U$ Antitrust Officials Have B2B Exchanges in Sights, ExcrTe News, July 23, 2000 (discussing merger and consolidation of internet companies); John R. Wilke, FTC Opens Antitrust Inquiry into Plan by Big 3 Car Makers for Online Venture, WALL ST. J., Mar. 22, 2000, at A6 (same).

189. See, e.g., James Gleick, Patently Absurd, N.Y. Times, Mar. 12, 2000, magazine at 44 (discussing appropriateness of issuing patents for e-commerce concepts), available at http://www.nytimes.com/library/magazine/home/20000312 mag-patents.html. For a primer on the issuance of e-commerce patents, see Jason Coombs \& Ted Coombs, The Golden Year Of Opportunity, Byte, Mar. 13, 2000, which is available at http://www.byte.com/column/ BYT20000301S0003.

190. See Lawrence Lessig, The Limits of Copyright, STANDARD, June 19, 2000 (discussing concern that overly strong intellectual property protections might have chilling effect on Internet development), available at http:// www.thestandard.com/article/display/1,1151,16071,00.html.

191. See, e.g., Anticybersquatting Consumer Protection Act (attempting to eliminate "cyber-piracy" by holding offenders civilly liable for intentionally using and profiting from trademarks, such as another's domain name), at http://frwebgate.access.gpo.gov/cgi-bin/ getdoc.cgi?dbname=106_cong_bills\&docid=f:s1255es.txt.pdf.

192. See, e.g., Uniform Computer Information Transactions Act (July 30, 1999) (noting that purpose of UCITA is to "clarify and set forth uniform legal principles applicable to computer information transactions"), at http:// www.law.upenn.edu/bll/ulc/ucita/UCITA_99.htm. Despite its history and name, UCITA is more about IP than sales. See Mark K. Anderson, Now, UCITA . . Later, You Don't?, Standard, Mar. 3, 2000, at 16 (discussing Virginia's newest legislation regarding software licensing), available at http://www.thestandard.com/article/ display/0,1151,12615,00.html; Jeri Clausing, Virginia Is First with Controversial Software Law, N.Y. Times, Mar. 14, 2000, at A8 (same), at http://www.nytimes.com/ 
tions v. Rural Telephone Service Co. ${ }^{193}$ is under continual attack from Congress, ${ }^{194}$ and college students listening to MP3s are subject to criminal prosecution under the NET Act, ${ }^{195}$ or similarly draconian state laws, ${ }^{196}$ at a time when millions of Internet users view copyright as irrelevant-with all the moral authority of the speed limit. ${ }^{197}$

Retrofitting privacy law in the face of e-vendors' massive established databases of personal and financial information will be even more problematic. ${ }^{198}$ These databases contain information that is integrated and coherent. The information has been collected clandestinely or from gullible consumers who have traded their privacy for free services or convenience (e.g., through personalization). Despite concern voiced by our trading

library/tech/00/03/cyber/capital/14capital.html. See generally Bad Software: A Consumer Protection Guide (discussing consumer rights after receiving defective software), at http://www.badsoftware.com (last modified Sept. 16, 2000).

193. 499 U.S. 340, 349 (1991) (holding that names, towns and telephone numbers of utility subscribers are facts unable to be copyrighted).

194. See, e.g., Harvey Berkman, Congress Tackles Database Law, NAT'L L.J., July 26, 1999, at B1 (discussing two pending bills in U.S. House of Representatives that may resolve issues arising from subsequent use of databases by unauthorized users), available at http://www.lawnewsnetwork.com/practice/techlaw/news/ A3661-1999Jul21.html.

195. See No Electronic Theft Act of 1997, Pub. L. No. 105-147, 111 Stat. 2678 [hereinafter NET Act] (heightening criminal copyright infringement protections). See generally Andy Patrizio, DOJ Cracks Down on MP3 Pirate, Wired, Aug. 23, 1999 (discussing Department of Justice prosecution of MP3 case), available at http:// www.wired.com/news/print_version/politics/story/21391.html; Jennifer Sullivan, MP3 Pirate Gets Probation, WIRED, Nov. 24, 1999 (discussing sentencing of convicted MP3 pirate), available at http://www.wired.com/news/print/0,1294,32276,00. html. See generally May 1, 2000 Revision to Sentencing Guidelines Stemming from the 1997 No Electronic Theft Act, Jan. 21, 1998 (including copyright violations via electronic means as grounds. for criminal infringement), at http:// www.gseis.ucla.edu/iclp/hr2265.html.

196. See, e.g., 1999 Wis. Laws 51, 943.207(3m) (b) (stating that:

[w] hoever violates this section is guilty of a Class D felony under any of the following circumstances: 1 . If the person transfers sounds into or onto fewer than 1,000 recordings or advertises, offers for sale or rent, sells, rents, possesses or transports fewer than 1,000 recordings in violation of sub. (1) during a 180-day period, and the value of the recordings excess $\$ 2,500 ; 2$. If the person transfers sounds on or to the Internet in violation of sub. (1), the transferred sounds are replayed by others from the Internet fewer than 1,000 times during a 180-day period, and the value of the transferred sounds involved in the violation exceeds $\$ 2,500$ ).

197. See, e.g., Amy Harmon, Potent Software Escalates Music Industry's Jitters, N.Y. Times, Mar. 7, 2000, at Al (discussing music industry's response to availability of music from Napster and other online services), available at http://www.nytimes. com/library/tech/00/03/biztech/articles/07net.html.

198. For a compelling discussion of the difficulty of reconciling the massive volumes of personal information available on the Internet with current privacy law, see LESSIG, infra note 224, at 142-63. 
partners ${ }^{199}$ and advocacy groups, ${ }^{200}$ almost nothing has been done to halt the process, ${ }^{201}$ and it is difficult to see how the commercial databases can be flushed. In efforts that amount to "too little, too late," the FTC has begun the process of protecting children from the data collectors. ${ }^{202}$

Notwithstanding a decade of lawyer jokes, in human-intermediated commerce the transactional lawyer is viewed as an asset, increasing the comprehensibility of documents, lowering parties' information costs and, by routing transactions through common, low-friction systems, lowering other transaction costs as well. Nevertheless, e-commerce law is always inefficient, adding costs to an almost friction-free process. ${ }^{203}$

199. For a discussion of the European Parliament's concerns, see supra text accompanying note 181 .

200. See, e.g., Electronic Privacy Information Center (noting that EPIC was established to focus public attention on emerging civil liberties and protection of privacy), at http://www.epic.org.

201. The FTC has been limited to taking action against e-commerce sites that breach their own standards. See, e.g., Online Auction Site Settles FTC Privacy Charge, Federal Trade Commission, Jan. 6, 2000 (discussing online auction site's deceptive scam), at http://www.ftc.gov/opa/2000/01/reverse4.htm. The agency is now actively seeking additional powers. See Federal Trade Commission Report to Congress, Privacy Online: Fair Information Practices in the Electronic Marketplace, May 2000 (discussing consumer concerns about privacy in electronic marketplace), at http:/ /www.ftc.gov/reports/privacy2000/privacy2000.pdf.

The Department of Health and Human Services has made considerably more progress in protecting confidential health data. See U.S. Department of Health and Human Services, Subpart E-Privacy of Individually Identifiable Health Information (stating that “[a] covered entity may not use or disclose an individual's protected health information" unless certain requirements are met), available at http://www.erm.aspe.hhs.gov/ora_web/plsql/

erm_rule.rule_text?user_id=\&crule_id=290\#164SubE (last visited Feb. 18, 2001). The FTC and other government agencies have also been granted some limited powers under the Gramm-Leach-Bliley Act, Pub. L. 106-102, 133 Stat. 1338 (codified at 15 U.S.C. 6712) (2000). See, e.g., 16 C.F.R. 313.1 (2000) (authorizing agencies to issue regulations that may be necessary to implement notice requirements and restrictions on ability of financial institutions to disclose nonpublic personal information to third parties).

202. See Children's Online Privacy Protection Act (COPPA), July 17, 1998 (outlawing website operators from collecting personal information from children without parental disclosure), available at http://www.cmcnyls.edu/USLaws/ S2326IS.htm; Children's Online Privacy Protection Rule: Issuance of Final Rule, 16 C.F.R. pt. 312 (Oct. 20, 1999) (requiring commission to enact rules governing online collection of personal information from children under age thirteen within one year of COPPA's enactment), available at http://www.ftc.gov/os/1999/9910/ childrensprivacy.pdf. See generally Pamela Mendels, Web Companies and Parents Take In New Rules on Children's Sites, N.Y. TImes, Oct. 30, 1999 (discussing reaction of several Internet companies to COPPA), available at http://www.nytimes.com/library/tech/99/10/cyber/articles/30coppa.html.

203. See generally Bill Gates, The RoAd AHEAd (1995) (discussing impact of technology and evolution of Internet in government and business roles). Notwithstanding, Robert P. Merges identifies transaction costs, albeit much lower ones, in negotiation, performance and enforcement. See Robert P. Merges, The End of Friction? Property Rights and Contract in the "Newtonian" World of On-Line Commerce, 12 BERKELEY TECH. L.J. 115, 116 (1997) (noting that, in general, cyberspace does not appear to lower negotiation costs). 
This type of skepticism regarding law as increasing transaction costs is already present when it comes to real space dispute resolution. As a result, there will be compounded problems in persuading e-commerce players to have anything to do with the traditional law-based dispute resolution systems. The legal system may become marginalized, reduced to occasional forays into overseeing the operation of web-based dispute resolution services $^{204}$ and arbitration or mediation systems built into e-commerce engines. ${ }^{205}$

\section{Transactional Law}

Moving commerce and most transactions to the web will impact most areas of business and commercial law. A fluid time of disaggregation and re-aggregation will confuse our systems and require fresh analyses of appropriate risk allocation. Highly efficient markets will lead to razor thin margins and extreme volatility as cost transparency ${ }^{206}$ and high-churn, click-loyalty paradigms reign. ${ }^{207}$ For commercial lawyers, the next few years will see a radical reworking of our payments law and a robust bankruptcy practice. Labor lawyers will face a continued rise in robotic systems, thus taking the semi-skilled out of the industrial employment and accident law scenarios, ${ }^{208}$ while white-collar employment will pose its own issues as it continues to embrace independent contractor, telecommuting and home-based models.

The most far-ranging changes and the ones that will have the most impact on the curriculum, however, are essentially transactional in nature. Transactional law will have to cope with a shift from products to services and the impact of disintermediation. These forces will play out in both

204. See, e.g., The Total Solution to Revolution (discussing Click N Settle's alternative online dispute resolution services), available at http://www.clicknsettle. com (last visited Feb. 18, 2001); Cybersettle (discussing Cybersettle's online method for settling insurance claims), available at http://www.cybersettle.com; see also John Caher, New Rules for Domain Arbitration Produce Results, N.Y.L.J., Mar. 14, 2000 , at 1 (discussing New York dispute in which retailer won cyberspace trademark rights), available at http://www.lawnewsnetwork.com/stories/A18566-2000 Mar13.html.

205. See, e.g., Ebay.com (using SquareTrade to offer dispute resolution systems for its users), at http://www.squaretrade.com.

206. See generally Indrajit Sinha, Cost Transparency: The Net's Real Threat to Prices and Brands, HARV. Bus. REv., Mar.-Apr. 2000, at 43 (discussing impact of e-commerce on business in current markets), available at http://www.hbsp.harvard.edu/ products/hbr/ marapr00/R00210.html.

207. See Marc Ferranti, The Net Changes Everything. Now What?, IDG News SERV., Apr. 28, 1999 (“[C]ustomers will be kings [because on the Internet, customers have] click loyalty. They'll stick around as long as they like the prices or what's being said."), available at http://www.pcworld.com/cgi-bin/pcwtoday?ID=10740.

208. See, e.g., AG Systems (discussing benefits of line of GPS-enabled farming products), available at http://www.beelinenavigator.com. 
$\mathrm{B} 2 \mathrm{~B}$ and $\mathrm{B} 2 \mathrm{C}$ transactions ${ }^{209}$ and have a fundamental effect on the substance and structure of our commercial, consumer and business curriculum.

The functionality and value of a networked appliance will depend on the services that run on or through it. In real space, lawyers have successfully drawn distinctions between services and products. Relatively clean doctrinal distinctions have resulted. Nonetheless, in cyberspace the distinctions will not be as clean, and services will become the dominant transaction. Furthermore, in a disaggregated world there is no guarantee that the product and the services are provided by the same legal entity. Related to this will be the gradual substitution of tangible goods with digital goods. If video and music files can be delivered via broadband, ${ }^{210}$ you don't need $\mathrm{CD}$ retailers (whether or not on the web) or, soon, neighborhood video rental stores.

In e-commerce, disintermediation ${ }^{211}$ describes several different scenarios. Intermediaries most at risk are those that trade in information rather than create content or value-add, such as real estate agents, ${ }^{212}$ stockbrokers, ${ }^{213}$ travel agents, ${ }^{214}$ insurance agents ${ }^{215}$ and, soon, car dealers. ${ }^{216}$ However, the concept can also be applied to the replacement of real space distribution with Internet distribution. Disintermediation is a complex and dynamic concept. For example, in the music industry the retailer is a traditional intermediary that may be removed by direct Internet sales of MP3-based music by record labels. Equally, the record com-

209. See Chip Bayers, The Bot.Com Future, WIRED, Mar. 2000, at 210 (discussing fluid markets and dynamic pricing), available at http://www.wired.com/wired/ archive $/ 8.03 /$.

210. See, e.g., Andrew Pollack, Online Music Gets a Lift in AOL Deal with Warner, N.Y. TIMES, Jan. 18, 2000, at C8 (discussing implications of AOL-Time Warner merger on future of online music), available at http://www.nytimes.com/library/ tech $/ 00 / 01 /$ biztech/articles/ 18music.html.

211. See generally Don Willmott, Disintermediation: The Buzzword from Hell, PC MaG., Sept. 10, 1997 (defining "disintermediation" as act of shutting out middleman), available at http://www.zdnet.com/pcmag/insites/willmott/dw970910.htm.

212. See, e.g., Realtor.com (providing example of online realtor), at http:// www.realtor.com.

213. See, e.g., etrade.com (providing example of online brokerage account web site), at http://www.etrade.com.

214. See, e.g., Previewtravel.com (providing example of online travel agent), available at http://www.previewtravel.com.

215. See epolicy.com (providing example of online insurance agent), at http:/ /www.epolicy.com; Statefarm.com (same), at http://www.statefarm.com. See generally Susan E. Fisher, Internet Shakeup for Insurance, INFOwORLD, Feb. 21, 2000, at 34 (same); Bob Tedeschi, Insurance Companies Cautiously Enter the Internet Waters, N.Y. TIMEs, Mar. 20, 2000 (discussing online insurance companies), available at http:// www.nytimes.com/library/tech/00/03/cyber/commerce/20commerce.html.

216. See, e.g., CarsDirect.com (providing example of online car retailer), at http:// www.carsdirect.com; see also Keith Bradsher, Pushing for a Crackdown on Auto Sales Done Directly Online, N.Y. Times, Jan. 25, 2000, at C1 (discussing attempts to prohibit online car dealerships), available at http://www.nytimes.com/library/financial/012500auto-dealers.html. 
pany itself could be removed from the transaction if the musician starts distributing his or her products directly to consumers over the Internet. ${ }^{217}$

In some cases, disintermediated transactions are attracting a new species of intermediaries - a process of reintermediation. For example, there is a thriving business for Internet services that supply information about transactions or parties-digital intermediaries or infomediaries. ${ }^{218}$ Many B2B services are essentially studies in reintermediation, making highly fragmented markets efficient with the use of infomediaries. ${ }^{219}$ Reintermediation also may occur at a purely automated level. Thus, many of the more successful reintermediated services are shopping agents, 'bots, bidding services, ${ }^{220}$ or group buying services.

At first sight one would think that in a disintermediated world with thick markets where consumers have perfect information, the need for consumer protection law in $\mathrm{B} 2 \mathrm{C}$ transactions would decline. However, in practice we will have to navigate oligopolistic tendencies ${ }^{221}$ and determine the status and liability regimes for infomediaries and other third parties such as certification authorities. Equally, we will have to navigate the prevalent click-wrap paradigm, including the possibility of using technological solutions akin to those proposed by the World Wide Web Consortium to mediate acceptable levels of privacy. ${ }^{222}$

\section{E. Cyberspace Access Law}

During the first decade of the information age, "cyberspace law" has tended to be a container for law impacted by computer mediation, usually consisting of extrapolations from real space fact patterns. As a subject, it has attracted both near ridicule ${ }^{223}$ and sophisticated defense. ${ }^{224}$ There

217. For a discussion of the impact of the Internet on the music industry, see supra note 197 and accompanying text.

218. See generally James Glave, Saffo: Leave That Middleman Alone, WiRed, Apr. 17, 1998 (same), available at http://www.wired.com/news/business/ 0,1367,11756,00.html; Alex Gove, Dissing Disintermediation, VCs Seek to Improve Markets, Not Change Them, RED HerRING MAG., Feb. 1998 (discussing burgeoning business of web intermediating), available at http://www.redherring.com/mag/ issue51/whispers.html.

219. See, e.g., Chemdex.com (providing example of online retailer of scientific products), at http://www.chemdex.com.

220. See, e.g., Nextag.com (providing example of online bidding service), at http://www.nextag.com; Michelle Slatalla, Reviving the Fine Art of Haggling, Online, N.Y. Times, Jan. 20, 2000, at D4 (discussing new wave of online bidding services), available at http://www.nytimes.com/library/tech/00/01/circuits/articles/ 20shop.html.

221. See generally Chip Bayers, Capitalist Econstruction, Wrred, Mar. 2000 (conceptualizing future of e-commerce), available at http://www.wired.com/wired/ archive/ 8.03/markets.html.

222. See Platform for Privacy Preferences Project (P3P) (discussing W3's proposed regulations to ensure internet privacy), at http://www.w3.org/P3P.

223. See Frank H. Easterbrook, Cyberspace and the Law of the Horse, $1996 \mathrm{U}$. CHI. LeGAL F. 207, 207 (mocking "cyberlaw" as separate legal field).

224. See, e.g., Lawrence Lessig, Code and Other Laws of Cyberspace (1999). 
exist now, however, unique issues that require comment and scholarship. With the clumsy label "access law," I attempt to capture issues as diverse as the "digital divide" and the access of ISPs to broadband pipes. If the metaphor for the legal system for the last decade of the Twentieth Century was the class action against a managed care organization, so we will greet the second decade of the Information Age with similar actions against those who are viewed as controlling the Internet. To an extent, this area of law will be the place to process the inevitable backlash to the Information Age. ${ }^{225}$ The parties will range from the poor to the Amish, from Luddites to computer terrorists. ${ }^{226}$

The core access issue involves the cost of access and hence the true digital divide issue as it relates to the poor and historically disadvantaged groups. ${ }^{227}$ But there will also be more subtle variations as those in rural areas seek to gain the same type of access that vendors rush to install in high population areas. So, in addition, the slow movement to universal provision of basic Internet services will change the perspective of the provision of broadband services. We will also have to meet the challenge of access to services by the disabled ${ }^{228}$ and other discrimination issues such as redlining. ${ }^{229}$

The issue of access will increasingly tie in with employment issues. Employers will increasingly seek to control the cyber-lives of their employees, at first in the traditional office situation, but subsequently in the home offices for which they supply connectivity or hardware. State employees are already under increasingly strong regulation, ${ }^{230}$ while organized labor

225. See Bill Joy, Why the Future Doesn't Need Us, WIred, Apr. 2000 (arguing that genetic engineering and robotics are threatening to make humans endangered species), available at http://www.wired.com/wired/archive/8.04/joy.html. Joy is co-founder and Chief Scientist of Sun Microsystems. See id.

226. See Lessig, supra note 224 , at 58-60.

227. See Americans in the Information Age Falling Through the Net, United States Department of Commerce, Oct. 2000 (discussing attempt by Commerce Department to understand how information revolution is affecting nation), available at http://www.ntia.doc.gov/ntiahome/digitaldivide.

228. See generally Standards for Federal Electronic and Information Technology, The Architectural and Transportation Barriers Compliance Board, Mar. 31, 2000 (discussing standards for compliance with internet services for disabled), available at http://www.access-board.gov/sec508/nrpm.htm; Carl S. Kaplan, Is Cyberspace a 'Public Accommodation?', N.Y. Times, Nov. 15, 1999 (same); Pamela Mandels, Lawsuit Says AOL Shuts Out the Blind, N.Y. Times, Nov. 4, 1999 (same), available at http:// www.nytimes.com/library/tech/99/11/ cyber/articles/04blind.html; The Archimedes Project (same), available at http://www-csli.stanford.edu/arch/arch.html.

229. See, e.g., Martha M. Hamilton, Web Retailer Kozmo Accused of Redlining, WASH. Post, Apr. 14, 2000, at E03 (discussing complaint filed against Kozmo, online company that delivers CDs, alleging that Kozmo delivered only to principally white zip codes), available at http://www.washingtonpost.com/wp-dyn/articles/ A9719-2000Apr13.html.

230. See, e.g., Urofsky v. Gilmore, 167 F.3d 191, 192 (4th Cir. 1999) (challenging constitutionality of Virginia law restricting state employees from viewing sexually explicit web sites on state-owned computers). 
will have to battle to gain access to employer-owned networks ${ }^{231}$ and employer-provided home computers.

\section{Conclusion}

Not surprisingly, given the above, I take a firm stand on the emergence of DE in the legal education market. There is no "if" about the distance learning debate, only a "when." Our law schools must adopt a click-and-brick model for three primary reasons. First, customers demand it. Second, the click-and-brick model has the potential to capture the best of both computer-mediated and traditional legal education. Finally, this model is the best model with which law schools can compete with the pure-play, Internet-only law schools that will seek to fill our space. This vision of the hybrid law school utilizing traditional, distributive and distance pedagogies may not be dystopian, but neither is it a comfortable compromise. I have concentrated on the next five to ten years of legal education-what I call the second decade of the Information Age. Given the exponential growth of the Internet and its enabling technologies, however, the dismemberment or destruction of traditional service-providing institutions such as law schools has only begun. ${ }^{232}$

Adding Ethernet and a few data projectors to a law school building will not convert the traditional law school into a robust click-and-brick player capable of resisting an onslaught from both familiar and new competitors leveraging their content and technological muscle in the distance learning space. Neither will any such limited approach to computer mediation and instruction be adequate to prepare our students for their practice careers. The absorption and leveraging of computer-mediated instruction and related services must be deep-seated and robust, reaching beyond the law school digerati to the heretofore secular. The technological demands made by our future customers and the voracity of our competitors seeking to fill educational space will quickly expose any tokenism.

Law schools must avoid being trapped in defensive positions, merely mimicking in real space what others are doing better in virtual space while

231. See Noam S. Cohen, Comporations Battling to Bar Use of E-Mail for Unions, N.Y. Times, Aug. 23, 1999, at C1 (discussing union fight for e-mail rights), available at http://www.nytimes.com/library/tech/99/08/biztech/articles/23unio.html; Steven Greenhouse, A.F.L.-C.I.O. Members to Get On-line Access and Discounts, N.Y. Times, Oct. 11, 1999, at Cl (discussing A.F.O.-C.I.O. members receiving online access at workplace), available at http://www.nytimes.com/library/tech/99/10/ biztech/articles/11work.html.

232. See Peter W. Martin, The Internet: "Full and Unfettered Access" to Lawsome Implications, 26 N. Ky. L. REv. 181, 183-84 (1999) (using irresistible comparison between legal profession and Encyclopedia Britannica); see also Eli M. Noam, Electronics and the Dim Future of the University, Sci., Oct. 13, 1995, at 247-49 (discussing universal servers and storage problems), available at http://www.asis.org/annual$96 /$ noam.html. 
hoping that the next population bulge will rescue them. ${ }^{233}$ We need to reestablish the value proposition of the law school and exploit the pieces of technology that do things better than the traditional methods and tools. Alongside the robust technology and training, we still need more professionalism in our marketing and increased expectations of our professional organizations. We must strive to make the law school real space superior and real space experiences "sticky." We need continued rigor in our teaching and more collaboration within the different skill sets represented in a modern law school. We need to weed the curriculum and hire faculty members who both understand computer-mediated education and are sensitive to the legal implications of web space and the interaction of law and technology.

As I have thought about these issues, I have done so in a spirit of guarded optimism as to the future of legal education. I am acutely aware, however, that the majority of those involved in traditional law school endeavors see no "opportunity" 234 in the growth of computer-mediated education or DE, and certainly no excitement in the process of discovery that we will be undertaking in the next decade. Indeed, I am acutely aware that the "promise" of distributive and distance teaching is viewed as the exact opposite, an anathema, by many of my colleagues.

The good news is that the distance learning issue finally has brought the idea of technology as an agent of change into the law school debate. The bad news is that the true impact of technology on law and legal education arguably is still not fully understood, and that concentration on the distance learning issue might obscure more fundamental issues. Our pedagogy and curriculum is in grave danger of fossilization as we enter the second decade of the information age. If nothing else, the $\mathrm{DE}$ revolution should force us into a major reevaluation of both, while re-engineering for a click-and-brick future promises the greatest hope that academics can continue to positively influence the development of our laws and institutions.

233. For a discussion of growth in traditional law schools, see supra note 74 and accompanying text.

234. I use this literally and as referenced in the Ferengi Rules of Acquisition 6 and 9. See University of Glasgow (noting frequently asked questions about aliens in Star Trek), available at http://www.dcs.gla.ac.uk/ hwloidl/FAQL-aliens-rasm.html \#RoA. 